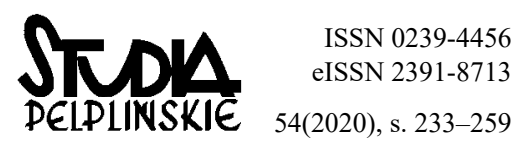

SEWERYN PAUCH

sewerynpauch@wp.pl

ORCID: 0000-0003-1714-7351

\section{ŚLADY DOLKOWE NA OBSZARZE POLSKI - KATALOG}

DOI: http://dx.doi.org/10.12775/SPLP.2020.011

\begin{abstract}
Streszczenie
Prezentowany tekst jest zestawieniem miejscowości z obszaru całej Polski, w których znajdują się świątynie posiadające na swych elewacjach ślady dołkowe. Celem niniejszego tekstu jest wskazanie rozległości występowania tak charakterystycznego zjawiska, które pozostaje niejednoznacznie rozpoznane w swej genezie. Przedstawiony katalog pozwala też prześledzić zmiany zachodzące w ilości śladów zinwentaryzowanych przez kolejnych badaczy, co wskazuje jednoznacznie na zanikanie przedmiotowych otworów.
\end{abstract}

Słowa kluczowe: ślady dołkowe, katalog, XVI-XVIII w., religijność, kościoły gotyckie

Cup Marks in the Polish Territory: a Catalogue

\section{Summary}

The paper provides a catalogue of places scattered around Poland with churches having cup marks in their facades. The purpose of this research is to account for the frequency of this distinctive phenomenon whose origins remain partially undermined. The catalogue also helps to follow the diminishing number of traces observed by various researchers which proves their gradual disappearance over time.

Keywords: cup marks, catalogue, $16^{\text {th }}-18^{\text {th }}$ century, religiousness, gothic churches 
Przedmiotem niniejszego wykazu są zagłębienia, które w zdecydowanej większości znajdują się na gotyckich kościołach, rzadziej na innych obiektach sakralnych, jak krzyże pokutne, sporadycznie występujące na ossuariach. Są one osobliwością widoczną również na głazach narzutowych, a także budowlach o charakterze świeckim (gotyckie bramy i wieże). Tytułowe ślady dołkowe określa się pospolicie mylnym mianem dołków pokutnych, bardziej zaś trafnie w badaniach polskich z lat 80/90 - tych XX w. czarkami, jamkami, śladami po świdrach ogniowych, nieckowatymi zagłębieniami czy śladami dołkowymi ${ }^{1}$. Otwory te mają formę dwojaką, przy czym rzeczone nazwy służą określeniu dołków o regularnym, okrągłym charakterze (fot. 1); znacznie rzadziej przyjmują one kształt podłużnych rynienek czy też bruzd (fot. 2). Przyjmuje się, iż powstały one w okresie od XVI do XVIII w.

Geneza śladów dołkowych nie jest jednoznacznie wyjaśniona. Rozwój badań nad tym problemem wskazuje na wielkie prawdopodobieństwo pochodzenia ich od czynności rozpalania ognia „świętego”, ,żywego”, „bożego” od murów budowli sakralnych przy użyciu specjalnego, drewnianego świdra ${ }^{2}$. Inna hipoteza - popularna w badaniach na terenie Europy zachodniej - wywodzi ich powstanie od czynności pozyskiwania pyłu ceglanego ze sfery sacrum (stanowił ją mur kościoła), który bywał wykorzystywany do czynności zabobonnych, zwykle mających na celu podłoże zdrowotne. Wyniki badań polskich, prowadzonych na przestrzeni ostatnich lat, wydają się potwierdzać, iż drugie ze wspomnianych założeń posiada większe znamiona prawdopodobieństwa od hipotezy „ogniowej”, co też czyni je priorytetowym. Jednocześnie jednak nie wyklucza to istnienia dualizmu w kwestii przyczyn, dla których reminiscencją są ślady dołkowe, a więc czynności prowadzące do ich wytworzenia mogły mieć dwojaką genezę̧.

1 Nazwa ta sugeruje ich pochodzenie od czynności ekspiacyjnej, jaką w ramach pokuty zadanej przez duchownych mieli wykonywać wierni.

2 Na temat tej hipotezy zob. J. Hochleitner, Tajemnicze znaki na cegłach gotyckich kościołów na przykładzie katedry św. Mikołaja w Elblagu, „Rocznik Elbląski”, t. XVIII, 2002, s. 99; J. Lewandowska, Zagadkowe ślady na murach kościołów w Brodnicy, Lembargu, Lubawie i Nowym Mieście Lubawskim, w: Wiara z demonem w tle. Studia nad materialnymi śladami przekazu informacji na ziemiach polskich do schytku XVIII wieku, Wydawnictwo Adam Marszałek, Toruń 2008, s. 74; A. Mietz, Nowożytne graffita i ślady oczyszczania ogniem w Polsce Środkowej i Pólnocnej, w: Wiara z demonem w tle. Studia nad materialnymi śladami przekazu informacji na ziemiach polskich do schyłku XVIII wieku, Wydawnictwo Adam Marszałek, Torun 2008, s. 123; J. Tyszkiewicz, ,Nowy ogień” na wiosnę, w: Cultus et cognitio. Studia z dziejów średniowiecznej kultury, Państwowe Wydawnictwo Naukowe, Warszawa 1976, s. 593; T. Wróblewski, Zagadkowe ślady na ścianach kościołów w Wielkopolsce, „Studia i Materiały do Dziejów Wielkopolski i Pomorza", t. 4 (1958), z. II, s. 203-204.

3 S. Pauch, Ślady dotkowe na murach kościołów gotyckich na terenie wybranych diecezji Polski pótnocnej (praca doktorska w zbiorach UKW w Bydgoszczy), Bydgoszcz 2018; K. Węgłowska, Nieckowate zagłębienia na elewacjach średniowiecznych obiektów sakralnych na obszarze ziemi chetmińskiej i lubawskiej (praca doktorska w zbiorach UMK w Toruniu), Torun 2016. 


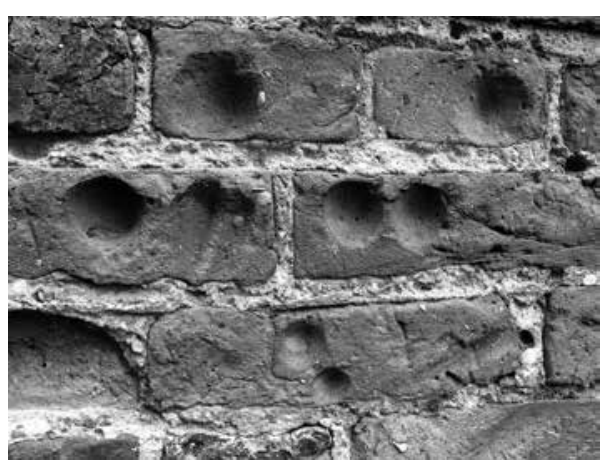

Fot. 1. Ślady dołkowe z kościoła w Starym Targu (fot. własna)

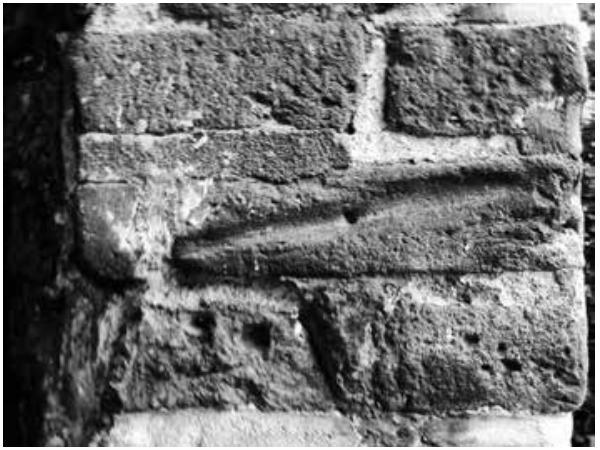

Fot. 2. Ślad podłużny na tczewskiej Farze (fot. własna)

Należy podkreślić, iż podobne katalogi nie powstały wcześniej, nie licząc pracy Andrzeja Mietza, opublikowanej w 2008 r. ${ }^{4}$ Grupa badaczy, którzy podjęli analizę zagadnienia, jakim jest geneza i funkcje śladów dołkowych i przebadali w tym celu co najmniej kilkanaście miejscowości na terenie Polski jest nieliczna. Na gruncie rodzimych badań zaliczają się do nich (poza A. Mietzem) Janusz Hochleitner, Jadwiga Lewandowska, Seweryn Pauch i Katarzyna Węgłowska ${ }^{5}$. Niniejszy tekst uwzględnia także rozprawy autorów spoza polskiego obszaru nauki (np. badania niemieckie), o ile dotyczą one miejscowości położonych obecnie w granicach administracyjnych Polski. Nie wzięto jednak pod uwagę analogicznych katalogów, dotyczących badań prowadzonych poza naszym krajem, dla terenów Niemiec czy szerzej - Europy Zachodniej6.

Wykaz zawiera miejscowości znajdujące się na terenie Polski, których nazwy pojawiły się w literaturze znanej autorowi. Uwzględniono niemal wyłącznie ślady na świątyniach gotyckich, sporadycznie na romańskich i jednym ossuarium (w Bystrzu). W przypadku części świątyń podano w nawiasie ich wezwanie, zgodnie ze stanem podawanym w literaturze dotyczącej śladów na danej budowli. Należy poczynić uwagę, że wśród nich są takie, na których obecnie nie można już

4 A. Mietz, Nowożytne graffita, dz. cyt., s. 115-123.

5 J. Hochleitner, Kubki i pręgi na krzyżackich kościołach, „Przydrożne Pomniki Przeszłości”, 1993, z. XVI, s. 24-28; J. Lewandowska, Zagadkowe ślady na murach wybranych kościołów w Polsce pótnocno-wschodniej, w: Zjawiska magiczno-demoniczne na terenie dawnych ziem pruskich na tle porównawczym, red. K. Grążawski, J. Gancewski, Wydawnictwo Uniwersytetu Warmińsko-Mazurskiego, Olsztyn 2014, s. 177-189; S. Pauch, Ślady dołkowe na murach kościołów gotyckich, dz. cyt., s. 105; K. Węgłowska, dz. cyt., katalog.

6 Np. P. Schels, Schabespuren auf Stein (Rillen und Näpfchen) - http://www.yumpu.com/de/ document/view/8703752/schabespuren-auf-stein-rillen-und-napfchen-hosting-agency [15.12.2019]; J. Weertz., E. Weertz, Ch. J. Duffin, Possible sources of therapeutic stone powder from North West Europe, "Pharmaceutical Historian", t. XLIV, nr II, s. 27-32. 
zlokalizować śladów dołkowych, jednak w przeszłości niektórzy autorzy dostrzegli je tam.

Katalog został sporządzony w kolejności alfabetycznej. W przypisie do każdej miejscowości znajduje się stosowna literatura, w której dana miejscowość została wspomniana, z podaniem ilości śladów okrągłych i podłużnych (o ile takie informacje zawarto w poświęconej im publikacji). Wykaz wzbogacono danymi ze stron internetowych, na których można coraz częściej znaleźć informacje o śladach, przy czym szczególne miejsce zajmują wśród nich fora internetowe eksploracja.pl i straznicyczasu.pl. Pierwsze zawiera m.in. wykazy informacji na temat otworów na murach świątyń w Polsce północnej, zaś drugie prezentuje analogiczne informacje dla południowych regionów kraju. Dla potrzeb niniejszego tekstu zastosowano skróty, występujące w przypisach: d - dołki (ślady okrągłe); p - pręgi (ślady podłużne); ś - ślady (dla podania ogólnej liczby śladów dołkowych - jeżeli autorzy nie podali, czy chodzi o ślady okrągłe, czy podłużne); AAM (Archiwum Andrzeja Mietza) ${ }^{7}$.

Spośród prac drukowanych, najwięcej informacji wnoszących pożądane dane znajduje się w cytowanym wyżej katalogu autorstwa zasłużonego badacza śladów dołkowych - Andrzeja Mietza.

\section{Wykaz miejscowości ze śladami:}

Barciany (Niepokalanego Serca NMP) ${ }^{8}$, Barczewo (św. Anny) ${ }^{9}$, Bartąg ${ }^{10}$, Bartoszyce $^{11}$, Bądkowo (św. Mateusza) ${ }^{12}$, Bągart ${ }^{13}$, Bielawy (Nawiedzenia NMP) ${ }^{14}$,

7 Dzięki uprzejmości małżonki i córki tego badacza, miałem możliwość wglądu w jego rękopiśmienne archiwum, które pozwoliło mi następnie wzbogacić wykaz o szereg informacji (np. data inwentaryzacji śladów, dokładniejsza ich liczba).

8 A. Mietz, Nowożytne graffita, dz. cyt., s. 121 - 12ś.; AAM (badania z 1998 r.); http://www.forum. eksploracja.pl/viewtopic.php?f=142\&t=9570 [28.11.2017].

9 J. Hochleitner, Kubki i pręgi, dz. cyt., s. 26 - ok. 50 d.; A. Mietz, Nowożytne graffita, dz. cyt., s. 121 - 52ś.; AAM (50 d. - badania z 1996 r.); badania własne - $50 \mathrm{~d}$.

10 Badania własne $-8 \mathrm{~d}$.

11 A. Mietz, Nowożytne graffita, dz. cyt., s. 121 - 36 ś.; AAM (34 d., 2 p. - badania z 1997 r.).

12 A. Mietz, J. Pakulski, „Corpus Inscriptionum Poloniae”, t. IV (Kujawy brzeskie), s. 29; A. Mietz, Nowożytne graffita, dz. cyt., s. 123 - 338 ś.; tenże, Zbawienie i potępienie w świadectwach nowożytnych graffiti. Ze studiów nad staropolska religijnościa masowa poludniowego pogranicza kujawsko-wielkopolskiego, w: Studia z dziejów południowego pogranicza kujawsko-wielkopolskiego, red. P. Szczepankiewicz, Wydawnictwo Propaganda, Włocławek-Wierzbinek 2010, s. 18; AAM (338d., 6p. - badania z 1995 r.); badania własne - 238d.

13 Badania własne - 123 ś.

14 Tenże, Nowożytne graffita, s. 117 - 224ś.; http://webcache.googleusercontent.com/search?q=cache:http://meteor2017.bikestats.pl/1578125, Weekend-13ego-1-Z-Soboty-na-Piatek.html\&gws rd=cr\&dcr=0\&ei=-li1WZjiM6qg6ASjr4foDQ [28.11.2017]; AAM (215d., 9p. - badania z 1997 r.). 
Błędowo ${ }^{15}$, Bobrowo (św. Jakuba Apostoła) ${ }^{16}$, Bolesławiec ${ }^{17}$, Boreczno ${ }^{18}$, Boręty (św. Katarzyny) ${ }^{19}$, Braniewo (św. Katarzyny) ${ }^{20}$, Brąswałd ${ }^{21}$, Brodnica (św. Katarzyny) ${ }^{22}$, Brudzew ${ }^{23}$, Brześć Kujawski (św. Stanisława) ${ }^{24}$, Butryny ${ }^{25}$, Byczyna ${ }^{26}$, Bydgoszcz (św. Mikołaja) ${ }^{27}$, Bydgoszcz (NMP Królowej Pokoju) ${ }^{28}$, Bydgoszcz (Wniebowzięcia NMP, ,klaryski”) ${ }^{29}$, Bystrze (ossuarium) ${ }^{30}$, Byszwałd (św. Andrzeja) ${ }^{31}$, Bytom Odrzański (św. Hieronima) ${ }^{32}$, Bytyń ${ }^{33}$, Cedry Wielkie (Świętych

15 Badania własne - $1 \mathrm{~d}$.

16 A. Mietz, Nowożytne graffita, dz. cyt., s. 120 - 9ś.; AAM (5d., 4p. - badania z 1996 r.).

17 Grempler, Ueber Altertümliches in Bunzlau, "Jahresbericht der Schlesischen Gesellschaft für vaterländische Cultur" 1893, s. 53.

18 K. Madela, Tajemnicze znaki na cegłach kościoła św. Antoniego w Suszu, „Skarbiec Suski”, 2009, nr I, s. 9; badania własne - 14d.

19 S. Pauch, Wybrane przejawy religijności na murach budowli sakralnych Wielkich Żuław Malborskich, „Studia Pelplińskie”, t. 47(2015), s. 206 - 32ś.; http://www.forum.eksploracja.pl/ viewtopic.php? $\mathrm{f}=142 \& \mathrm{t}=9570($ dostęp 28.11.2017).

20 A. Mietz, Nowożytne graffita, dz. cyt., s. 121 - 117ś.; http://www.forum.eksploracja.pl/viewtopic. php?f=142\&t=9570; https:/czaykowska.com/2009/08/27/dziury-w-ceglach/ [28.11.2017]; AAM (114d., 3p. - badania z 1997 r.); badania własne - 101ś.

21 J. Lewandowska, Zagadkowe ślady na murach wybranych kościołów, s. 179 - 7ś.; http://www. forum.eksploracja.pl/viewtopic.php? $\mathrm{f}=142 \& \mathrm{t}=9570$ [28.11.2017].

22 Tenże, Zagadkowe ślady na murach kościołów w Brodnicy, dz. cyt., s. 58 - 168ś.; tenże, Zagadkowe ślady na murach wybranych kościołów, dz. cyt., s. 179 - 166ś.; A. Mietz, Nowożytne graffita, dz. cyt., s. 120 - 168ś.; K. Węgłowska, dz. cyt., s. 26 - 166ś.; http://www.czasbrodnicy. pl/czasbrodnicy/1,93191,22518255,skad-sie-wziely-dziury-w-farze.html [28.11.2017]; http:// www.czasbrodnicy.pl/czasbrodnicy/1,93191,12040429,Tajemnicze_znaki_na_farze.html [28.11.2017]; AAM (163d. - 40 - $160 \mathrm{~cm}, 3$ p. - badania z 1996 r.); badania własne - $-150 \mathrm{~d}$.

23 A. Mietz, Nowożytne graffita, dz. cyt., s. 123 - 28ś.; AAM (26d., 2p. - badania z 1987 r.).

24 Badania własne - $1 \mathrm{~d}$.

25 A. Mietz, Nowożytne graffita, dz. cyt., s. 121 - 3ś.; AAM (3d. - badania z 1999 r.).

26 Fogel J., Frapująca zagadka średniowiecznych światyń, „Przegląd Wielkopolski”, 35-36(1996), s. 17; https://silesion.pl/najszczesliwsze-miasto-na-swiecie-02-07-2017 [28.11.2017]; http: //www.straznicyczasu.pl/viewtopic.php? $\mathrm{f}=57 \& \mathrm{t}=6630 \&$ sid=29da05fca67afe9ec1ebdede2613b$86 \mathrm{c} \&$ start $=40$ [28.04.2019].

27 J. Fogel, dz. cyt., s. 16; A. Mietz, Nowożytne graffita, dz. cyt., s. 115 - 152́́.; AAM (43d., 38p. badania z 1996 r.); badania własne (28d., 22p.).

28 Tenże, Nowożytne graffita, dz. cyt., s. 115 - 19 ś.

29 Tamże, s. 115 - 45ś.; AAM (45ś. - badania z 1996 r.).

30 S. Pauch, Wybrane przejawy, dz. cyt., s. $206-9$ d.

31 A. Mietz, Nowożytne graffita, dz. cyt., s. 120 - 6ś.; K. Węgłowska, dz. cyt., s. 26 - 10d.; AAM (6d. - badania z 1996 r.); badania własne - 3d.

32 M. Hellmich, Nochmals die Teufelskrallen und Näpfchen an alten Bauwerken, "Korrespondenzblatt des Gesamtvereins der Deutschen Geschichts - und Altertumsvereine", 1918 nr III/IV, s. 75 - ponad 100ś.; J. A. Drozdowski, Kubki, pręgi..., „Przydrożne Pomniki Przeszłości”, 1986, z. II, s. 6; http://www.krajoznawcy.info.pl/znaki-pokuty-i-dobrych-interesow-8315 [28.11.2017].

33 A. Mietz, Nowożytne graffita, dz. cyt., s. 118 - 22ś.; AAM (21d.,1p. - badania z 1996 r.). 
Aniołów Stróżów) ${ }^{34}$, Cerekwica k. Żnina ${ }^{35}$, Chełmno (NMP) ${ }^{36}$, Chełmno (pofran-

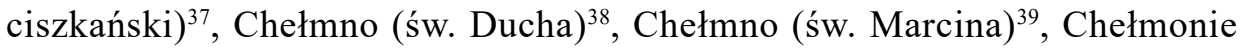
(św. Bartłomieja) ${ }^{40}$, Chełmża (św. Mikołaja ${ }^{41}$, Chełmża (św. Trójcy) ${ }^{42}$, Chęciny

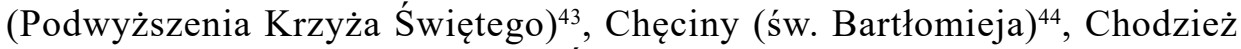
(śś. Mikołaja i Floriana) ${ }^{45}$, Chojnice (Ścięcia św. Jana Chrzciciela) ${ }^{46}$, Choszczno ${ }^{47}$, Chruślin (św. Michała) ${ }^{48}$, Chwarszczany $^{49}$, Czarnkowo $^{50}$, Czarnków $^{51}$, Czarnowo $^{52}$,

34 A. Mietz, Nowożytne graffita, dz. cyt., s. 116-29ś.; http://www.forum.eksploracja.pl/viewtopic. php? $\mathrm{f}=142 \& \mathrm{t}=9570$ [28.11.2017]; AAM (26d.,3p. - badania z $1998 \mathrm{r}$.); badania własne $-11 \mathrm{~d}$.

35 A. Mietz, Nowożytne graffita, dz. cyt., s. 116 - 8ś.; AAM (8d., 0p. - badania z 1995 r.); badania własne $-19 \mathrm{~d}$.

36 A. Mietz, Nowożytne graffita, dz. cyt., s. 120 - 115ś.; K. Węgłowska, dz. cyt., s. 26 - 9ś.; AAM (115d. - badania z 1996 r.; badania własne - 4ś.

37 A. Mietz, Nowożytne graffita, dz. cyt., s. 120 - 8ś.; AAM (8d. - badania z 1996 r.).

38 A. Mietz, Nowożytne graffita, dz. cyt., s. 120 - 10ś.; K. Węgłowska, dz. cyt., s. 26 - 3d.; AAM (10d. - badania z 1996 r.).

39 Badania własne $-2 \mathrm{~d}$.

40 A. Mietz, Nowożytne graffita, dz. cyt., s. 120 - 46ś.; K. Węgłowska, dz. cyt., s. 26 - 52 d., 8p.; AAM (41d., 5p. - badania z 1996 r.); badania własne - 31d.

41 A. Mietz, Nowożytne graffita, dz. cyt., s. 120 - 38ś.; K. Węgłowska, dz. cyt., s. 26 - 2d., 1p.; AAM (38d. - kilkanaście p. - badania z 1995 r.); badania własne - 2d.

42 A. Mietz, Nowożytne graffita, dz. cyt., s. 120 - 143ś.; K. Węgłowska, dz. cyt., s. 26 - 35d., 4p.); AAM (143d., 23p. - badania z 1995 r.); badania własne - 26d., 3p.

$43 \mathrm{http}: / /$ www.straznicyczasu.pl/viewtopic.php?t=6630 [28.11.2017].

$44 \mathrm{http}: / /$ www.straznicyczasu.pl/viewtopic.php?t=6630 [28.11.2017].

${ }^{45}$ AAM (ś. są zakryte tynkiem).

46 W. Brzoskowski, Dzieje Skarszew, Skarszewy 2009, s. 50; J. Hochleitner, Kubki i pręgi, dz. cyt., s. 24 - 798d., 75p.; tenże, Tajemnicze znaki na cegłach gotyckich kościołów, dz. cyt., s. 101 798ś.; K. Kamińska, Zagłębienia na cegłach z chojnickiej bazyliki, „Baszta”, t. 11(2011), s. 37-43; A. Mietz, Nowożytne graffita, dz. cyt., s. 117 - 888ś.; I. Sołtyk, Graffiti czasów nowozytnych na murach Bazyliki pod wezwaniem Ścięcia św. Jana Chrzciciela w Chojnicach. Studium analityczne, Przedsiębiorstwo Marketingowe Logo, Chojnice 2011, s. 47 - 218ś.; S. Pauch, Ślady na murach bazyliki pw. Ścięcia św. Jana Chrzciciela w Chojnicach, „Zeszyty Chojnickie”, 2015, nr XXXI, s. 64 - 248ś.; AAM (ponad 170d., 11p.); badania własne - 233d., 15p.

47 A. Mietz, Nowożytne graffita, dz. cyt., s. 119 - 412ś.; AAM (409d., 3p.).

$48 \mathrm{http}: / /$ webcache.googleusercontent.com/search? $\mathrm{q}=$ cache:http://meteor2017.bikestats. pl/1578125, Weekend-13ego-1-Z-Soboty-na-Piatek.html\&gws_rd=cr\&dcr=0\&ei=li1WZjiM6qg6ASjr4foDQ [28.11.2017].

$49 \mathrm{http} / /$ www.forum.eksploracja.pl/viewtopic.php? $\mathrm{f}=142 \& \mathrm{t}=9570 \&$ start $=40$ [28.11.2017].

50 A. Mietz, Nowożytne graffita, dz. cyt., s. 118 - 11ś.

51 J. Olędzki, Znaki istnienia, „Polska Sztuka Ludowa”, R. XXXIX, 1985, nr I - II, s. 14; AAM (11d. - badania z 1996 r.).

52 A. Mietz, Nowożytne graffita, dz. cyt., s. 120 - 7ś.; AAM (7d. - badania z 1996 r.). 
Czarże $^{53}$, Czerniejewo ${ }^{54}$, Czernikowo ${ }^{55}$, Dąbrówka (diecezja pelplińska) ${ }^{56}$, Dąbrówka Królewska (św. Jakuba) ${ }^{57}$, Dąbrówno ${ }^{58}$, Dębno ${ }^{59}$, Dębowa Łąka (św.św. Piotra i Pawła) ${ }^{60}$, Dobiegniew ${ }^{61}$, Dobre Miasto (Najświętszego Zbawiciela i Wszystkich Świętych) ${ }^{62}$, Dobrowoda (św. Marii Magdaleny) ${ }^{63}$, Dolsk ${ }^{64}$, Drawsko Pomorskie (Zmartwychwstania Pana Naszego Jezusa Chrystusa) ${ }^{65}$, Drobin $^{66}$, Duszniki ${ }^{67}$, Dywity ${ }^{68}$, Dzierzgoń ${ }^{69}$, Dzietrzychowo ${ }^{70}$, Dźwierzno ${ }^{71}$, Elbląg (Bożego Ciała) ${ }^{72}$, Elbląg - Próchnik ${ }^{73}$, Elbląg (św. Mikołaja) ${ }^{74}$, Fiszewo

53 A. Mietz, Nowożytne graffita, dz. cyt., s. 120 - 4ś.; AAM (4d.) - było więcej, ale cegły zwietrzały badania z $1996 \mathrm{r}$.

54 AAM (7d.).

55 A. Mietz, Nowożytne graffita, dz. cyt., s. 123 - 45ś.; Idem, Apotropaiony antydemoniczne na świątyniach ziemi dobrzyńskiej, „Rocznik Muzeum Ziemi Dobrzyńskiej w Rypinie”, t. I, 2009, s. 91, s. 95 - 46ś.; AAM (45d.).

56 A. Mietz, Nowożytne graffita, dz. cyt., s. 117 - 58d.; I. Sołtyk, dz. cyt., s. 51 - 58d.; AAM (58d. badania z 1998 r.).

57 K. Węgłowska, dz. cyt., s. 26 - 28d., 2p.; badania własne - 20d., 1p.

58 A. Mietz, dz. cyt., s. 121 - 52ś. - badania z 1998 r.

59 Tamże, s. $118-59$ ś.

${ }^{60}$ K. Węgłowska, dz. cyt., s. $26-2$ d.

61 A. Mietz, Nowożytne graffita, dz. cyt., s. 123 - 200ś.; http://www.straznicyczasu.pl/viewtopic. php?t=6630 [28.11.2017]; http://www.woldenberg-neumark.eu/St/Woldenberger_Kirche. html\#loecher [28.11.2017]; AAM (173d.,7p. - badania z 1998 r.).

62 A. Mietz, Nowożytne graffita, dz. cyt., s. 121 - 55ś.; http://www.forum.eksploracja.pl/viewtopic. php?f=142\&t=9570 [28.11.2017]; https://czaykowska.com/2009/08/27/dziury-w-ceglach/ [28.11.2017]; AAM (55d. - badania z 1996 r.; badania własne - 78d.).

$63 \mathrm{http}: / /$ www.straznicyczasu.pl/viewtopic.php?t=6630 [28.11.2017].

${ }^{64}$ A. Mietz, Nowożytne graffita, dz. cyt., s. 118 - 59ś.; AAM (11d. - badania z 1995 r.).

65 A. Mietz, Nowożytne graffita, dz. cyt., s. 117 - 33ś.; http://www.forum.eksploracja.pl/viewtopic. php?f=142\&t=9570 [28.11.2017]; AAM (33d. - badania z 1998 r.).

66 A. Mietz, Nowożytne graffita, dz. cyt., s. 118 - 21ś.; AAM (21d. - badania z 1996 r.).

67 A. Mietz, Nowożytne graffita, dz. cyt., s. 118 - 3ś.; AAM (3d.).

68 Tamże (10d., 2p. - badania z 1998 r.).

69 A. Mietz, Nowożytne graffita, dz. cyt., s. 116 - 3ś.; AAM (2d, 1p.).

70 A. Mietz, Nowożytne graffita, dz. cyt., s. 121 - 13ś.; AAM (8d., 5p. - badania z 1998 r.).

71 A. Mietz, Nowożytne graffita, dz. cyt., s. 120 - 115ś.; AAM (115 d. - niepewne, może pochodzenia atmosferycznego - badania z 1996 r.).

$72 \mathrm{http} / /$ www.forum.eksploracja.pl/viewtopic.php?f=142\&t=9570 [28.11.2017]; badania własne $-48 d ., 9 p$.

73 Badania własne - 19ś.

74 J. Hochleitner, Kubki i pręgi, dz. cyt., s. 25 (kilkaset kubków i pręg); tenże, Tajemnicze znaki na cegłach gotyckich kościołów, dz. cyt., s. 95, 101 (w marcu 1992 r. - 1054ś.); P. Szczepański, Kubki i pręgi na kościele św. Mikołaja w Elblagu, „Przydrożne Pomniki Przeszłości”, 1993, z. XVI, s. 28-29 - 1054d., 238p.; A. Mietz, Nowożytne graffita, dz. cyt., s. 116 - 1043ś.; http:// www.forum.eksploracja.pl/viewtopic.php? $\mathrm{f}=142 \& \mathrm{t}=9570$ [28.11.2017]; AAM (763d., 132p. badania z 1996 r.); badania własne - 938d., 41p. 
$(\text { ruiny })^{75}$, Frombork (św. Ducha) ${ }^{76}$, Frombork (św. Mikołaja) ${ }^{77}$, Frombork (Wniebowzięcia NMP i św. Andrzeja Apostoła) ${ }^{78}$, Gardeja (wieża, św. Józefa) ${ }^{79}$, Gdańsk (św. Jana) ${ }^{80}$, Gdańsk (św. Katarzyny) ${ }^{81}$, Gdańsk (św. Trójcy) ${ }^{82}$, Gdańsk (Wniebowzięcia NMP) ${ }^{83}$, Giebło (św. Jakuba) ${ }^{84}$, Głubczyce (Narodzenia NMP) ${ }^{85}$, Gniew (św. Mikołaja) ${ }^{86}$, Gniewkowo ${ }^{87}$, Gniezno ${ }^{88}$, Gniezno (św. Jerzego) ${ }^{89}$, Gniezno (św. Michała) ${ }^{90}$, Gniezno (św. Trójcy) ${ }^{91}$, Golub (św. Katarzyny) ${ }^{92}$, Gorzędziej ${ }^{93}$, Gorzów Wielkopolski (Wniebowzięcia NMP) ${ }^{94}$, Gosławice ${ }^{95}$, Gostkowo (WNMP) ${ }^{96}$,

75 S. Pauch, Ślady na murach bazyliki, dz. cyt., s. 64 (przy portalu głównym); http://www.forum. eksploracja.pl/viewtopic.php?f=142\&t=9570 [28.11.2017]; https://czaykowska.com/2009/08/27/ dziury-w-ceglach/ [28.11.2017].

76 Badania własne - 3d.

77 Badania własne - 98d., 28p.

$78 \mathrm{http}: / /$ www.forum.eksploracja.pl/viewtopic.php?f=142\&t=9570 [28.11.2017]; https://czaykowska. com/2009/08/27/dziury-w-ceglach/ [28.11.2017]; badania własne - 7d.

79 Badania własne - 115d., $4 \mathrm{p}$.

$80 \mathrm{http}: / /$ www.forum.eksploracja.pl/viewtopic.php?f=142\&t=9570 [28.11.2017]; badania własne $84 \mathrm{~d} ., 10 \mathrm{p}$.

81 A. Mietz, Nowożytne graffita, dz. cyt., s. 116 - 145ś.; AAM (są d. - na podstawie literatury, nie podaje jakiej); badania własne $-8 \mathrm{~d}$., $2 \mathrm{p}$.

82 AAM (są d. - na podstawie literatury, nie podaje jakiej).

${ }^{83}$ Ibidem (są d. - na podstawie literatury, nie podaje jakiej); badania własne - 31d.

84 D. Skonieczna-Gawlik, Tropem badaczy Zagtębia Dąbrowskiego, Katowice 2016, s. 231.

$85 \mathrm{http}: / /$ www.straznicyczasu.pl/viewtopic.php? $\mathrm{f}=57 \& \mathrm{t}=6630 \& \mathrm{sid}=3 \mathrm{c} 16 \mathrm{df} 30 \mathrm{c} 1 \mathrm{be}-$ 153a247656804e4986b7\&start=30 [28.11.2017].

86 A. Mietz, Nowożytne graffita, dz. cyt., s. 117 - 168ś.; J. Olędzki, dz. cyt., s. 14; S. Pauch, Ślady na murach kościoła św. Mikołaja w Gniewie, jako wyraz lęku przed nagła śmiercia, „Nasza Przeszłość", t. CXXV, 2016, s. 165-182-176ś.; http://www.forum.eksploracja.pl/viewtopic. php?f=142\&t=9570; https://czaykowska.com/2009/08/27/dziury-w-ceglach/ [28.11.2017]; AAM (157d., 11p.).

87 J. Fogel, dz. cyt., s. 16; A. Mietz, Nowożytne graffita, dz. cyt., s. 116 - 901ś.; tenże, Zbawienie i potepienie, dz. cyt., s. 18; AAM (757d., 144p. - badania z 1989 r.); badania własne - 1116d., $116 \mathrm{p}$.

88 J. Dydyński, Uwagi o wklęstościach kulistych na murze kościelnym, „Kurier Poznański”, nr 294; I. Sołtyk, dz. cyt., s. 47.

89 A. Mietz, Nowożytne graffita, dz. cyt., s. 116 - 81ś.; AAM (81d. - badania z 1996 r.).

90 A. Mietz, Nowożytne graffita, dz. cyt., s. 116 - 49ś.; AAM (49d. - badania z 1996 r.).

91 A. Mietz, Nowożytne graffita, dz. cyt., s. 116 - 123ś.; AAM (133 d., 10p. - badania z 1996 r.)

92 A. Mietz, Nowożytne graffita, dz. cyt., s. 120 - 208ś.; J. Olędzki, dz. cyt., s. 14; K. Węgłowska, dz. cyt., s. 26 - 146d., 31p.; AAM (141d., 67p. - badania z 1996 r.); badania własne - 94d., 14p.

93 A. Mietz, Nowożytne graffita, dz. cyt., s. 117 - 16ś.; AAM (16d. - badania z 1998 r.); badania własne $-2 \mathrm{~d}$.

94 F. Jaśkowiak, Okolice Poznania, Poznań 1972, s. 134; http://www.forum.eksploracja.pl/viewtopic.php?f=142\&t=9570 [28.11.2017]; http://architektura.pomorze.pl/?art_id=892 [28.11.2017].

95 A. Mietz, Nowożytne graffita, dz. cyt., s. 123 - 18ś., Z. Pęcherski, Konin - Koło - Turek. Przewodnik wycieczkowy, Poznań 1966, s. 62; AAM (15d., 3p.).

96 AAM (15d. - badania z 1995 r.). 
Gostyń $^{97}$, Góra k. Żnina ${ }^{98}$, Gralewo ${ }^{99}$, Grodziczno (św.św. Piotra i Pawła) ${ }^{100}$, Gronowo (św. Mikołaja) ${ }^{101}$, Grudziądz ${ }^{102}$, Gruta (Wniebowzięcia NMP) ${ }^{103}$, Gryfino $(\text { Narodzenia NMP) })^{104}$, Gubin ${ }^{105}$, Gubiny ${ }^{106}$, Iława (Przemienienia Pańskiego) ${ }^{107}$, Inowrocław (św. Mikołaja) ${ }^{108}$, Iwanowice ${ }^{109}$, Jabłowo koło Starogardu Gdań-

97 J. Kilarski, Przewodnik po Wielkopolsce, Poznań-Warszawa-Wilno-Lublin 1938, s. 207 (także Stary Gostyń - s. 207); A. Mietz, Nowożytne graffita, dz. cyt., s. 118 - 180ś.; K. Staszewski, Tajemnica ,wierconych dołków”, „Ziemia” 1966, s. 266; http://faragotykgostyn.pl/artykuly-content/208.html - ponad 200ś. [28.11.2017]; AAM(180d., 0p. - badania z 1996 r.).

98 J. Kilarski, dz. cyt., s. 147; A. Mietz, Nowożytne graffita, dz. cyt., s. 116 -2ś.; A. Mietz, Zbawienie i potępienie, dz. cyt., s. 18; H. Mróz, Graffiti czasów nowożytnych na murach kościoła w Górze koło Żnina, w: Studia z dziejów poludniowego pogranicza kujawsko-wielkopolskiego, red. P. Szczepankiewicz, Włocławek-Wierzbinek 2010, s. 21, 26 - 24ś.; I. Sołtyk, dz. cyt., s. 48; http://www.forum.eksploracja.pl/viewtopic.php? $\mathrm{f}=142 \& \mathrm{t}=9570 \&$ start $=140$ [28.11.2017]; AAM(6d., 0p. - badania z 1995 r.); badania własne - 9d.

99 A. Mietz, Nowożytne graffita, dz. cyt., s. 118 - 2ś.; AAM (2d., 0p. - badania z 1996 r.).

${ }^{100}$ A. Mietz, Nowożytne graffita, dz. cyt., s. 120 - 49ś.; K. Węgłowska, dz. cyt., s. 26 - 41d., 2p.; AAM (42d., 7p. - badania z 1996 r.); badania własne - 30d., 1p.

101 A. Mietz 2008, Nowożytne graffita, dz. cyt., s. 120 - 25ś.; K. Węgłowska, dz. cyt., s. 26 - 30 d.; AAM (25d. - badania z 1995 r.); badania własne - 17d.

102 J. Olędzki, dz. cyt., s. 13; A. Mietz, Graffita czasów nowożytnych na murach kościołów w Grudziądzu i okolicy. Tożsamość - orędownictwo - zbawienie, „Rocznik Grudziądzki” 1998, t. XIII, s. 47 - 321ś.; tenże, Nowożytne graffita, dz. cyt., s. 120 - 319ś.; K. Węgłowska, dz. cyt., s. 26 289d., 40p.; http://www.forum.eksploracja.pl/viewtopic.php?f=142\&t=9570\&sid=97e7b0dd35b8fda5cbb58d24a2986d23\&start=20 [28.11.2017]; http://www.graudenz.pl/ciekawostki/graffiti-na-murach-kosciola-sw-mikolaja/ [28.11.2017]; AAM(288d. - 31p. - badania z 1996 r.); badania własne $-212 \mathrm{~d}$.

${ }^{103}$ A. Mietz, Graffita czasów nowożytnych, dz. cyt., s. 47 - 31ś.; tenże, Nowożytne graffita, dz. cyt., s. 121 - 13ś.; K. Węgłowska, 26 - 18d.; AAM (13d., 0p. - szlifowane ściany - badania z 1996 r.); badania własne $-5 \mathrm{~d}$.

$104 \mathrm{http}: / /$ www.forum.eksploracja.pl/viewtopic.php?f=142\&t=9570; http://architektura.pomorze. $\mathrm{pl} /$ ?art_id=704 [28.11.2017].

105 J.A. Drozdowski, dz. cyt., s. 6.

${ }^{106}$ Badania własne - 3d.

107 J. Hochleitner, Kubki i pręgi, dz. cyt., s. 26 - 12ś.; J. Lewandowska, Zagadkowe ślady na murach wybranych kościołów, dz. cyt., s. 179 - 12ś.; K. Madela, dz. cyt., s. 9; A. Mietz, Nowożytne graffita, dz. cyt., s. 116 - 71ś.; http://www.forum.eksploracja.pl/viewtopic.php?f=142\&t=9570 [28.11.2017]; https://czaykowska.com/2009/08/27/dziury-w-ceglach/ [28.11.2017]; AAM (66d., 5 p.); badania własne $-10 \mathrm{~d}$.

108 AAM (12d., setki uległy zniszczeniu przez rozpad cegieł - badania z 1996 r.); badania własne $15 \mathrm{~d}$.

109 A. Mietz, Nowożytne graffita, dz. cyt., s. 117 - 48ś.; AAM (48d., 6p. - cegły zwietrzałe, ś. mogło być więcej). 
skiego $^{110}$, Jaryszów ${ }^{111}$, Jasna ${ }^{112}$, Jelonki ${ }^{113}$, Jeziernik ${ }^{114}$, Jędrzejów (św. Trójcy) ${ }^{115}$, Kalinowa k. Błaszek ${ }^{116}$, Kalisz ${ }^{117}$, Kalisz (św. Mikołaja) ${ }^{118}$, Kamień Pomorski ${ }^{119}$, Kamionna ${ }^{120}$, Kazanice (św. Jakuba Apostoła) ${ }^{121}$, Kaźmierz ${ }^{122}$, Kcynia ${ }^{123}$, Kętrzyn (św. Jerzego) ${ }^{124}$, Kielce (Wniebowzięcia NMP) ${ }^{125}$, Kisielice ${ }^{126}$, Kiwity ${ }^{127}$, Kle-

110 Badania własne $-4 \mathrm{~d}$.

${ }^{111} \mathrm{http}: / /$ www.straznicyczasu.pl/viewtopic.php?t=6630 [28.11.2017].

112 Badania własne - $1 \mathrm{~d}$.

${ }^{113}$ Badania własne - 368d., 17p.

114 S. Pauch, Wybrane przejawy, dz. cyt., s. 206 - 6ś.; badania własne - 10d., 6p.

$115 \mathrm{http}: / /$ www.straznicyczasu.pl/viewtopic.php?t=6630 [28.11.2017].

116 J. Fogel, dz. cyt., s. 17; A. Mietz, Nowożytne graffita, dz. cyt., s. 117 - 64ś.; A. Ruszkowski, Ślady po nieceniu ognia na murach kościołów województwa sieradzkiego, „Biuletyn ZW PTTK”, 1980, nr II(272), s. 17; AAM (64d. - badania z 1996 r.).

117 J. Fogel, dz. cyt., s. 16; A. Mietz, Nowożytne graffita, dz. cyt., s. 117 - 93ś.; J. Tyszkiewicz, dz. cyt., s. 594; T. Wróblewski, dz. cyt., s. 195, 199 („niektóre kościoły”, św. Mikołaja w Kaliszu).

118 AAM (93d., 0p. - badania z 1996 r.).

119 J. Fogel, dz. cyt., s. 17; A. Mietz, Nowożytne graffita, dz. cyt., s. 119; P. Mordal, Kubki i rysy na ścianach kościoła w Szamotułach, „Przydrożne Pomniki Przeszłości”, 1990, z. XI, s. 37; http:// architektura.pomorze.pl/?art_id=701 [28.11.2017]; http://zp.pl/kamien-pomorski-tajemnicakatedralnych-murow,artykul_1_534_0_30 [28.11.2017]; AAM (są na wysokości korpusu dorosłego człowieka).

${ }^{120}$ A. Mietz, Nowożytne graffita, dz. cyt., s. 118 - 28ś.; AAM (28d., 0p. - badania z 1996 r.).

${ }^{121}$ A. Mietz, Nowożytne graffita, dz. cyt., s. 121 - 22ś.; K. Węgłowska, dz. cyt., s. 27 - 19d.; AAM (19d., 3p. - badania z 1996 r.); badania własne - 16d.

122 A. Mietz, Nowożytne graffita, dz. cyt., s. 118 - 2ś.; AAM (2d., 0p. - wymiana cegieł przy restauracji - badania z 1996 r.).

${ }^{123}$ A. Mietz, Nowożytne graffita, dz. cyt., s. 116 - 2ś.; tenże, Zbawienie i potępienie, s. 18; AAM (0d., 2p.).

${ }^{124}$ J. Hochleitner, Kubki i pręgi, dz. cyt., s. 26 - 30d., 2p.; tenże, Tajemnicze znaki na cegłach gotyckich kościołów, dz. cyt., s. 100 (portal); A. Mietz, Nowożytne graffita, dz. cyt., s. 121 - 178ś. http://www.forum.eksploracja.pl/viewtopic.php?f=142\&t=9570 [28.11.2017]; AAM (178d. badania z 1998 r.).

${ }^{125}$ Ok. 75 śladów, głównie podłużnych, pewna ilość na wysokości ok. 4 m, co może świadczyć o przebudowie, kilka śladów na murze okalającym dawny cmentarz kolegiacki - Informacje powyższe pochodzą z wystąpienia mgra Michała Brzozy w dniu 22 maja 2014 r., zatytułowanego Wyżłobienia i ślady na murach bazyliki katedralnej pw. Wniebowstapienia NMP w Kielcach, które przedstawił podczas konferencji naukowej I Lubelska Wiosna Historyczna (22-24 maja 2015 r.); http://www.straznicyczasu.pl/viewtopic.php?t=6630 [28.11.2017]; http://em.kielce.pl/ publicystyka/w-imie-boga [28.11.2017].

${ }^{126}$ J. Lewandowska, Zagadkowe ślady na murach wybranych kościołów, dz. cyt., s. 179 - 6ś.

${ }^{127}$ Badania własne - 3d. 
czew $^{128}$, Klonówka ${ }^{129}$, Kłecko ${ }^{130}$, Kobylin (św. Stanisława) ${ }^{131}$, Kołbacz ${ }^{132}$, Koło (Podwyższenia Krzyża Świętego) $^{133}$, Kołobrzeg (WNMP) ${ }^{134}$, Konin (św. Bartłomieja) $)^{135}$, Kończewice (Matki Bożej Wniebowzięcia) ${ }^{136}$, Koronowo ${ }^{137}$, Kostrzyn (śś. Piotra i Pawła) $)^{138}$, Koszalin (Niepokalanego Poczęcia NMP) ${ }^{139}$, Kościan ${ }^{140}$, Kościelec Kaliski ${ }^{141}$, Kościelec Kolski ${ }^{142}$, Kościelna Jania ${ }^{143}$, Kościelna Wieś (św. Wawrzyńca) ${ }^{144}$, Kowalewo Pomorskie (św. Mikołaja) ${ }^{145}$, Kozłów Biskupi ${ }^{146}$, Koźliny ${ }^{147}$, Kraków - Ruszcza (św. Grzegorza Wielkiego) ${ }^{148}$, Kraków (św. Woj-

${ }^{128}$ A. Mietz, Nowożytne graffita, dz. cyt., s. 116; AAM (liczne d., kilka p.).

129 A. Mietz, Nowożytne graffita, dz. cyt., s. 117 - 12ś.; AAM (12d. - badania z 1998 r.); badania własne $-8 \mathrm{~d}$.

130 J. Dydyński, dz. cyt., nr 294; J. Fogel, dz. cyt., s. 16; H. Hockenbeck, Die Näpfchensteine an den Pfarrkirchen zu Klecko, Lekno, Rogasen und Wongrowitz, ,Zeitschrift der Historischen Gesellschaft für die Provinz Posen”, 1885, t. I, s. 118 - 314ś.; A. Mietz, Nowożytne graffita, dz. cyt., s. 116 - 145ś.; J. Tyszkiewicz, dz. cyt., s. 594; T. Wróblewski, dz. cyt., s. 195; AAM (314/138, kilkanaście p. - badania z 1995 r.); badania własne - 127d., 5p.

${ }^{131}$ A. Mietz, Nowożytne graffita, dz. cyt., s. 117 - 80ś.; AAM (80d., 0p. - badania z 1996 r.).

132 A. Mietz, Nowożytne graffita, dz. cyt., s. 119.

133 Tamże, s. 123 - 83ś.; AAM ( 83d., 0p. - badania z 1998 r.).

134 A. Mietz, Nowożytne graffita, dz. cyt., s. $117-211$ ś.

135 Tamże, s. 123 - 571ś.; https://www.lm.pl/aktualnosci/informacja/57627/W-trosce-o-zabytki [28.11.2017].

${ }^{136}$ A. Mietz, Nowożytne graffita, dz. cyt., s. 116-23ś.; S. Pauch, Wybrane przejawy, dz. cyt., s. 206 4ś.; http://www.forum.eksploracja.pl/viewtopic.php?f=142\&t=9570 [28.11.2017]; https://czaykowska.com/2009/08/27/dziury-w-ceglach/ [28.11.2017]; AAM (23d., 0p. - badania z 1996 r.).

${ }_{137}$ A. Mietz, Nowożytne graffita, dz. cyt., s. 115 - 1ś.; tenże, Zbawienie i potępienie, dz. cyt., s. 18; AAM (1d. - badania z 1998 r.).

138 AAM (101d.).

139 A. Mietz, Nowożytne graffita, dz. cyt., s. 117 - 52ś.; J. Olędzki, dz. cyt., s. 13; I. Sołtyk, dz. cyt., s. 47; AAM (46d., 6p. - badania z 1996 r.).

140 A. Mietz, Nowożytne graffita, dz. cyt., s. 118 - 15ś.; AAM (15d., 0p. - badania z 1996 r.).

141 A. Mietz, Nowożytne graffita, dz. cyt., s. 117 - 52ś.; AAM (52d. - badania z 1995 r.).

142 A. Mietz, Nowożytne graffita, dz. cyt., s. 123 - 28ś.; tenże, Zbawienie i potępienie, dz. cyt., s. 18; AAM (28d. - część w cegłach, część - 5 - w kamieniu - badania z 1998 r.).

${ }^{143}$ A. Mietz, Nowożytne graffita, dz. cyt., s. 117 - 30ś.; AAM (30d. - badania z 1998 r.); badania własne - 1d.

${ }^{144}$ A. Mietz, Nowożytne graffita, dz. cyt., s. 123 - 563ś.; A. Mietz, J. Pakulski, dz. cyt., s. 29; http:// www.forum.eksploracja.pl/viewtopic.php? $\mathrm{f}=142 \& \mathrm{t}=9570 \&$ start=100 [28.11.2017]; AAM (563d., kilka p. - badania z 1995 r.); badania własne - 403d.

${ }^{145}$ A. Mietz, Nowożytne graffita, dz. cyt., s. 121 - 25ś.; K. Węgłowska, dz. cyt., s. 27 - 29d., 3p; AAM (25d., 0p. - badania z 1996 r.); badania własne - 14d.

$146 \mathrm{http}: / /$ meteor2017.bikestats.pl/1580327,Szukajac-pociskow-w-oparach-bzu.html [28.11.2017]; http://tomi.blox.pl/2010/06/Cegly-kosciola-w-Kozlowie-Biskupim.html [28.11.2017].

${ }^{147} \mathrm{https} / / /$ czaykowska.com/2009/08/27/dziury-w-ceglach/ [28.11.2017].

${ }^{148}$ www.straznicyczasu.pl [28.11.2017]. 
ciecha) $^{149}$, Kraków (Kazimierz) (św.św. Katarzyny i Małgorzaty) ${ }^{150}$, Kraskowo (MB Częstochowskiej) ${ }^{151}$, Krerowo ${ }^{152}$, Krosno Odrzańskie ${ }^{153}$, Kruszwica ${ }^{154}$, Krzcię- $^{15}$ cice (św. Prokopa) ${ }^{155}$, Krzywe Koło ${ }^{156}$, Krzywiń (św. Mikołaja) ${ }^{157}$, Krzyżanowo ${ }^{158}$, Kurkocin (św. Bartłomieja) ${ }^{159}$, Kurzętnik (św. Marii Magdaleny) ${ }^{160}$, Kwidzyn (św. Jana Ewangelisty) ${ }^{161}$, Kwietniewo (Podwyższenia Krzyża Świętego) ${ }^{162}$, Lalkowy (św. Barbary) ${ }^{163}$, Legnica ${ }^{164}$, Lembarg (św.św. Piotra i Pawła) ${ }^{165}$, Lichnowy (św. Urszuli) ${ }^{166}$, Lidzbark Warmiński (św.św. Piotra i Pawła) ${ }^{167}$, Lignowy ${ }^{168}$, Lipica

149 www.straznicyczasu.pl - ponad 30 ś.; https://czaykowska.com/2009/08/27/dziury-w-ceglach/ [28.11.207]; http://wikimapia.org/36212396/p1/Do\%C5\%82ki-pokutne [28.11.2017].

${ }^{150}$ www.straznicyczasu.pl [16.08.2018].

${ }^{151} \mathrm{http}: / /$ www.forum.eksploracja.pl/viewtopic.php?f=142\&t=9570 [28.11.2017]; http://ketrzynnews. $\mathrm{pl} / 5907 /$ [28.11.2017].

152 A. Mietz, Nowożytne graffita, dz. cyt., s. 118 - 22ś.; AAM (14d., 8p. - badania z 1996 r.).

${ }_{153}$ J. A. Drozdowski, dz. cyt., s. 3, 6.

${ }^{154}$ A. Mietz, Nowożytne graffita, dz. cyt., s. 116 - 30 ś.; AAM (28d., 0p.).

155 www.straznicyczasu.pl [28.11.2017].

${ }^{156} \mathrm{http}: / /$ www.forum.eksploracja.pl/viewtopic.php?f=142\&t=9570 [28.11.2017]; https://czaykowska. com/2009/08/27/dziury-w-ceglach/ [28.11.2017].

${ }_{157} \operatorname{AAM}(5 \mathrm{~d} ., 0 \mathrm{p}$.).

158 J. Hochleitner, Kubki i pręgi, dz. cyt., s. 25 - 28ś.; tenże, Tajemnicze znaki na cegłach gotyckich kościołów, dz. cyt., s. 100, 101-102 (portal, 26ś.); S. Pauch, Ślady na murach bazyliki, dz. cyt., s. 64 (blisko portalu głównego); badania własne - 34d., 1 p.

159 A. Mietz, Nowożytne graffita, dz. cyt., s. 121 - 14ś.; K. Węgłowska, dz. cyt., s. 27 - 9d., 2p.; AAM (10d., 4p. - badania z 1996 r.); badania własne - 5d.

${ }^{160}$ J. Lewandowska, Zagadkowe ślady na murach wybranych kościołów, dz. cyt., s. 179 - 9ś.; A. Mietz, Nowożytne graffita, dz. cyt., s. 121 - 9ś.; K. Węgłowska, dz. cyt., s. 27 - 10d.; AAM (9d., 0p. - badania z 1996 r.); badania własne - 6d.

161 A. Mietz, Nowożytne graffita, dz. cyt., s. 116 - 6ś.; AAM (5d., 1p.).

${ }^{162}$ K. Madela, dz. cyt., s. 9; S. Pauch, Ślady na murach bazyliki, dz. cyt., s. 64 (blisko portalu głównego); https:/czaykowska.com/2009/08/27/dziury-w-ceglach [28.11.207]; /http://www.forum. eksploracja.pl/viewtopic.php? $\mathrm{f}=142 \& \mathrm{t}=9570$ [28.11.2017]; badania własne $-209 \mathrm{~d}$., 14p.

163 A. Mietz, Nowożytne graffita, dz. cyt., s. 118 -317ś.; http://www.forum.eksploracja.pl/viewtopic. php?f=142\&t=9570\&start=140 [28.11.2017]; AAM (314d. - badania z 1998 r.); badania własne $44 \mathrm{~d}$.

164 J.A. Drozdowski, dz. cyt., s. 4.

165 J. Lewandowska, Zagadkowe ślady na murach kościołów w Brodnicy, dz. cyt., s. 58 - 94ś.; tenże, Zagadkowe ślady na murach wybranych kościołów, dz. cyt., s. 179 - 94ś.; A. Mietz, Nowożytne graffita, dz. cyt., s. 121 - 94ś.; K. Węgłowska, dz. cyt., s. 27 - 66 d., 13p.; AAM (37d., 0p. - badania z 1996 r.); badania własne - 35d., 6p.

${ }^{166}$ S. Pauch, Wybrane przejawy, dz. cyt., s. 206 - 204ś.; http://www.forum.eksploracja.pl/viewtopic. php?f=142\&t=9570 [28.11.207]; https://czaykowska.com/2009/08/27/dziury-w-ceglach/ [28.11.2017]; badania własne - 114d., 78p.

167 A. Mietz, Nowożytne graffita, dz. cyt., s. 121 - 32ś.; AAM (32d. - cegły zwietrzałe - badania z 1996 r.); badania własne - 48d.

${ }^{168}$ A. Mietz, Nowożytne graffita, dz. cyt., s. 118 - 3ś.; AAM (2d., 1p. - badania z 1996 r.); badania własne -8 ś. 
(św.św. Piotra i Pawła) ${ }^{169}$, Lipinki (św.św. Piotra i Pawła) ${ }^{170}$, Lipno ${ }^{171}$, Lubawa (św. Anny) ${ }^{172}$, Lubiąż ${ }^{173}$, Lubiesz ${ }^{174}$, Lubieszewo (św. Elżbiety) ${ }^{175}$, Lubin ${ }^{176}$, Lublewo Gdańskie (NMP Królowej Korony Polskiej) ${ }^{177}$, Lubstów ${ }^{178}$, Lwowiec (Matki Boskiej Szkaplerznej) $)^{179}$, Lwówek ${ }^{180}$, Łabędnik ${ }^{181}$, Łasin $^{182}$, Łąkorz $^{183}$, Łekno $^{184}$, Łęg Probostwo ${ }^{185}$, Łobdowo (św. Małgorzaty) ${ }^{186}$, Łomża ${ }^{187}$, Łopatki (św. Marii Magdaleny) ${ }^{188}$, Łukta (Matki Boskiej Częstochowskiej) ${ }^{189}$, Mątowy

$169 \mathrm{http} / /$ www.forum.eksploracja.pl/viewtopic.php?f=142\&t=9570 [28.11.2017].

170 A. Mietz, Nowożytne graffita, dz. cyt., s. 121 - 12ś.; AAM (12d., 0p. - badania z 1996 r.); badania własne $-9 \mathrm{~d}$.

171 A. Mietz, Apotropaiony antydemoniczne, dz. cyt., s. 91; 95 - 17ś.; tenże, Nowożytne graffita, dz. cyt., s. 123 - 17ś.; J. Olędzki, dz. cyt., s. 14; AAM (14d., 3p.).

172 J. Hochleitner, Kubki i pręgi, dz. cyt., s. 27 - 205d., 22p.; tenże, Tajemnicze znaki na cegłach gotyckich kościołów, dz. cyt., s. 101 - 205ś.; J. Lewandowska, Zagadkowe ślady na murach kościołów w Brodnicy, dz. cyt., s. 58 - 413ś.; tenże, Zagadkowe ślady na murach wybranych kościołów, dz. cyt., s. 179 -413ś.; A. Mietz, Nowożytne graffita, dz. cyt., s. 121 -413ś.; I. Sołtyk, dz. cyt., s. 47; K. Węgłowska, dz. cyt., s. 27 -359d., 28p.; AAM (332d., 18p. - badania z 1996 r.); badania własne $-201 \mathrm{~d}$., 9 p.

173 J. Fogel, dz. cyt., s. 17; http://faragotykgostyn.pl/artykuly-content/208.html [28.11.2017].

174 A. Mietz, s. 117 - 12ś.; AAM (12 d. w ceglanym portalu).

175 S. Pauch, Wybrane przejawy, dz. cyt., s. 206 - 59ś.; badania własne-47d., 9p.; http://www.forum. eksploracja.pl/viewtopic.php?f=142\&t=9570 [28.11.2017].

${ }^{176}$ J. Kilarski, dz. cyt., s. 204-205; K. Staszewski, dz. cyt., s. 266.

177 Badania własne - $3 \mathrm{~d}$.

178 A. Mietz, Nowożytne graffita, dz. cyt., s. 123 - 6ś.; AAM (6d., 0p. - kościół szlifowany, mogło być więcej śladów).

179 A. Mietz, Nowożytne graffita, dz. cyt., s. 121 - 149ś.; http://www.forum.eksploracja.pl/viewtopic. php? $\mathrm{f}=142 \& \mathrm{t}=9570$ [28.11.2017]; AAM (127d., 27p. - badania z 1998 r.).

180 A. Mietz, Nowożytne graffita, dz. cyt., s. 118 - 12ś.; AAM (12d., 0p. - mogło być więcej, cegły są zwietrzałe - badania z 1996 r.).

181 A. Mietz, Nowożytne graffita, dz. cyt., s. 122 - 26ś.; AAM (26d. - badania z 1997 r.).

182 A. Mietz, Graffita czasów nowożytnych, dz. cyt., s. 47 -221ś.; tenże, Nowożytne graffita, dz. cyt., s. 121 - 224ś.; S. Pauch, Dołki pokutne w Easinie, ,Prowincja”, 2012, nr I(VII), s. 79 - 84d., 5p.; AAM (218d., 6p. - badania z 1996 r.).

${ }^{183}$ J. Lewandowska, Zagadkowe ślady na murach wybranych kościołów, dz. cyt., s. 179 - 13ś.; A. Mietz, Nowożytne graffita, dz. cyt., s. 121 - 36ś.; AAM (36d., 0p. - badania z 1996 r.); badania własne $-10 \mathrm{~d}$.

${ }^{184}$ J. Dydyński, dz. cyt., nr 294; J. Fogel, dz. cyt., s. 16; H. Hockenbeck, dz. cyt., s. 118 - 245ś.; J. Tyszkiewicz, s. 594; T. Wróblewski, s. 195; AAM (245d., są też p.); badania własne - 225d.

185 A. Mietz, Nowożytne graffita, dz. cyt., s. 118 - 160ś.; AAM (154d., 6p. - badania z 1996 r.).

${ }^{186}$ A. Mietz, Nowożytne graffita, dz. cyt., s. 121 - 4ś.; K. Węgłowska, dz. cyt., s. 27 - 2d.; AAM (4d., 0p.).

187 A. Mietz, Nowożytne graffita, dz. cyt., s. $117-95$ ś.

${ }^{188}$ Tamże, s. 121 - 10ś; K. Węgłowska, dz. cyt., s. 27 - 3d., 3p.; AAM (4d., 6p. - badania z 1996 r.).

${ }^{189}$ Badania własne - 6d. 
Wielkie (św.św. Apostołów Piotra i Pawła) ${ }^{190}$, Malbork (św. Jana Chrzciciela) ${ }^{191}$, Malbork (ratusz) ${ }^{192}$, Marynowy ${ }^{193}$, Międzyrzecz ${ }^{194}$, Mieronice (św. Jana Apostoła) ${ }^{195}$, Miłobądz ${ }^{196}$, Miłomłyn ${ }^{197}$, Miłoradz (św. Michała Archanioła) ${ }^{198}$, Mogilno (klasztor) ${ }^{199}$, Mokrsko Dolne k. Chęcin (romański) ${ }^{200}$, Mołtajny ${ }^{201}$, Morąg ${ }^{202}$, Moskorzew (św. Małgorzaty) ${ }^{203}$, Myślibórz ${ }^{204}$, Myślice (Wniebowstąpienia NMP) ${ }^{205}$, Narzym $^{206}$, Niedźwiadna ${ }^{207}$, Niedźwiedź ${ }^{208}$, Nieżywięć (św. Jana Chrzciciela) ${ }^{209}$, Nowe (św. Jerzego ${ }^{210}$, Nowe (św. Maksymiliana Kolbego) ${ }^{211}$, Nowe

${ }^{190}$ S. Pauch, Wybrane przejawy, dz. cyt., s. 206 - 1d.; badania własne - 1d.; https://czaykowska. com/2009/08/27/dziury-w-ceglach/ [28.11.2017]; http://www.forum.eksploracja.pl/viewtopic. php? $=142 \& \mathrm{t}=9570$ [28.11.2017].

191 A. Mietz, Nowożytne graffita, dz. cyt., s. 116 - 185ś.; AAM (167d., 18p. - badania z 1996 r.); badania własne $-3 \mathrm{~d}$.

192 AAM (30d., 0p.).

${ }^{193} \mathrm{http}: / /$ www.forum.eksploracja.pl/viewtopic.php?f=142\&t=9570 [28.11.2017]; https://czaykowska. com/2009/08/27/dziury-w-ceglach/ [28.11.2017].

194 A. Mietz, Nowożytne graffita, dz. cyt., s. 123 - 20ś.; AAM (20d. - badania z 1996 r.).

$195 \mathrm{http}: / /$ www.straznicyczasu.pl/viewtopic.php?t=6630 [28.11.2017].

196 A. Mietz, Nowożytne graffita, dz. cyt., s. 118 - 10ś.; AAM (10d. - badania z 1998 r.).

${ }_{197}$ Badania własne - 28d.

198 S. Pauch, Wybrane przejawy, dz. cyt., s. 206 - 11ś.; http://www.forum.eksploracja.pl/viewtopic. php?f=142\&t=9570 [28.11.2017]; http://czaykowska.com/2009/08/27/dziury-w-ceglach/ [28.11.2017]; badania własne - 7d., 4p.

199 Badania własne - ponad 100 d.; AAM (przy wejściach).

${ }^{200}$ J. Fogel 1996, dz. cyt., s. 17; P. Pilich, Jeszcze raz o ,, dotkach wierconych”, „Przydrożne Pomniki Przeszłości”, 1990 nr XI, s. 33; J. Tyszkiewicz, dz. cyt., s. 595; http://www.straznicyczasu.pl/ viewtopic.php?t=6630 [28.11.2017].

${ }^{201}$ A. Mietz, Nowożytne graffita, dz. cyt., s. 122 - 14ś.; AAM (14p. - badania z 1998 r.).

${ }^{202}$ J. Lewandowska, Zagadkowe ślady na murach wybranych kościołów, dz. cyt., s. 179 - 143ś.; http://www.forum.eksploracja.pl/viewtopic.php?f=142\&t=9570 [28.11.2017]; https://czaykowska. com/2009/08/27/dziury-w-ceglach/ [28.11.2017]; AAM (318d., 0p. - badania z 1996 r.); badania własne - 317d., 4p.

${ }^{203}$ Cz. Hadamik, Moskorzew i jego zabytki, „Ziemia Częstochowska”, T. XXXVI, s. 29; T. Chrzanowski, T. Kornecki, Sztuka Ziemi Krakowskiej, Kraków 1982, s. 58.

204 A. Mietz, Nowożytne graffita, dz. cyt., s. 119 - 6ś.; AAM (6d. - badania z 1998 r.).

${ }^{205} \mathrm{http}: / /$ www.forum.eksploracja.pl/viewtopic.php?f=142\&t=9570 [28.11.2027]; https://czaykowska. com/2009/08/27/dziury-w-ceglach/ [28.11.2017].

${ }^{206}$ Badania własne - 328d. (informacje pozyskane od pana Tadeusza Szambory z Narzymia).

207 A. Mietz, Nowożytne graffita, dz. cyt., s. 117 - 11ś.

${ }^{208}$ Tamże, s. 121 - 4ś.; AAM (4d., 0p. - badania z 1996 r.).

209 A. Mietz, Nowożytne graffita, dz. cyt., s. 121 - 56ś.; K. Węgłowska, dz. cyt., s. 27 - 32d., 42p.; AAM (38d., 18p. - badania z 1996 r.); badania własne - 21d., 29p.

210 A. Mietz, Nowożytne graffita, dz. cyt., s. 118 - 6́́s.; AAM (6d., 0p. - badania z 1996 r.).

211 A. Mietz, Nowożytne graffita, dz. cyt., s. 118 - 5ś.; AAM (5d., 0p. - badania z 1996 r.); badania własne $-2 \mathrm{~d}$. 
n. Wisłą (św. Mateusza) ${ }^{212}$, Nowe Kawkowo ${ }^{213}$, Nowe Miasto Lubawskie (św. Tomasza) $)^{214}$, Nowy Staw (św. Mateusza) ${ }^{215}$, Oborniki ${ }^{216}$, Okonin (św.św. Kosmy i Damiana) $)^{217}$, Oleśnica (św. Jana Apostoła) ${ }^{218}$, Olsztyn (św. Jakuba) ${ }^{219}$, Ołobok $^{220}$, Opalenica ${ }^{221}$, Opatów (św. Marcina z Tours) ${ }^{222}$, Orłowo (św. Barbary) ${ }^{223}$, Orłów ${ }^{224}$, Orneta (św. Jana Chrzciciela) ${ }^{225}$, Osice ${ }^{226}$, Osiek Rypiński ${ }^{227}$, Osiek Wielkii ${ }^{228}$, Ostaszewo (św. Jana Chrzciciela) ${ }^{229}$, Ostroróg ${ }^{230}$, Ostrowite k. Chojnic ${ }^{231}$, Ostrowite

${ }^{212}$ A. Mietz, Nowożytne graffita, dz. cyt., s. 118 -213ś.; J. Olędzki, dz. cyt., s. 13; http://www.forum. eksploracja.pl/viewtopic.php?f=142\&t=9570 [28.11.2017]; AAM (194d., 9p. - badania z 1996 r.); badania własne $-47 \mathrm{~d} .7 \mathrm{p}$.

${ }^{213}$ Badania własne - $1 \mathrm{~d}$.

${ }^{214}$ J. Lewandowska, Zagadkowe ślady na murach kościołów w Brodnicy, dz. cyt., s. 58 - 252ś.; tenże, Zagadkowe ślady na murach wybranych kościołów, dz. cyt., s. 179 - 252ś.; A. Mietz, Nowożytne graffita, dz. cyt., s. 121 - 252ś.; I. Sołtyk, dz. cyt., s. 47; K. Węgłowska, dz. cyt., s. 27 - 271d.,4p.;AAM (102d.,0p. - badania z 1996 r.); badania własne - 150d.

${ }^{215}$ S. Pauch, Wybrane przejawy, dz. cyt., s. 206 - 43ś.; http://www.forum.eksploracja.pl/viewtopic. php?f=142\&t=9570; https://czaykowska.com/2009/08/27/dziury-w-ceglach/ [28.11.2017]; badania własne - 19d., 6p.

${ }^{216}$ A. Mietz, Nowożytne graffita, dz. cyt., s. 118 - 49ś.; AAM (49d. - na szkarpie, gdyż reszta jest tynkowana, 0p. - badania z 1996 r.).

217 A. Mietz, Graffita czasów nowożytnych, dz. cyt., s. 47 - 18ś.; tenże, Nowożytne graffita, dz. cyt., s. 121 - 18ś.; K. Węgłowska, dz. cyt., s. 27 - 8 d., 2p.; AAM (18d., 3p. - badania z 1996 r.); badania własne -1 d., $3 p$.

${ }^{218} \mathrm{http}: / /$ www.forum.eksploracja.pl/viewtopic.php?f=142\&t=9570 [28.11.2017]; https://czaykowska. com/2009/08/27/dziury-w-ceglach/ [28.11.2017].

${ }^{219}$ J. Hochleitner, Kubki i pręgi, dz. cyt., s. 27 - 565d.; tenże, Tajemnicze znaki na cegłach gotyckich kościołów, dz. cyt., s. 101 - 565ś.; A. Mietz, Nowożytne graffita, dz. cyt., s. 122 - 557ś.; http:// www.forum.eksploracja.pl/viewtopic.php? $\mathrm{f}=142 \& \mathrm{t}=9570$ [28.11.2017]; AAM (247d., 10p. badania z 1995 r.); badania własne - 314d., 42p.

${ }^{220}$ T. Lisiewicz, W sprawie kamieni ze śladami, „Światowit”, 1902, t. IV, s. 157; A. Mietz, Nowożytne graffita, dz. cyt., s. 117; T. Wróblewski, dz. cyt., s. 201.

221 A. Mietz, Nowożytne graffita, dz. cyt., s. 119 - 6ś.; AAM (6d., 0p. - badania z 1996 r.).

${ }^{222}$ P. Pilich, dz. cyt., s. 33; http://em.kielce.pl/publicystyka/w-imie-boga; [28.11.2017].

${ }^{223}$ S. Pauch, Wybrane przejawy, dz. cyt., s. 206 - 10ś.; badania własne - 8d., 2p.

${ }^{224}$ A. Mietz, Nowożytne graffita, dz. cyt., s. 117 - 70ś.; AAM (62d., 8p. - badania z 1997 r.).

${ }^{225}$ A. Mietz, Nowożytne graffita, dz. cyt., s. 122 - 93ś.; http://www.forum.eksploracja.pl/viewtopic. php?f=142\&t=9570 [28.11.2017]; AAM (93d., 0p. - badania z 1996 r.); badania własne $-28 \mathrm{~d}$.

${ }^{226} \mathrm{https} / /$ czaykowska.com/2009/08/27/dziury-w-ceglach/ [28.11.2017]; badania własne - 18d., 1p.

${ }^{227}$ AAM (52d. w ceglanym portalu - badania z 1994 r.).

${ }^{228}$ A. Mietz, Apotropaiony antydemoniczne, dz. cyt., s. 91, 95 - 52ś.; tenże, Nowożytne graffita, dz. cyt., s. 118.

${ }^{229}$ S. Pauch, Wybrane przejawy, dz. cyt., s. 206 - 22ś.; http://www.forum.eksploracja.pl/viewtopic. php?f=142\&t=9570 [28.11.2017]; https://czaykowska.com/2009/08/27/dziury-w-ceglach/ [28.11.2017]; badania własne - 21d.,1p.

${ }^{230}$ A. Mietz, Nowożytne graffita, dz. cyt., s. 119 - 175ś.; AAM (175d., 0p. - badania z 1996 r.).

${ }^{231}$ W. Brzoskowski, Dzieje Skarszew, dz. cyt., s. 50; A. Mietz, Nowożytne graffita, dz. cyt., s. 118 162ś.; http://www.forum.eksploracja.pl/viewtopic.php?f=142\&t=9570\&start=100 [28.11.2017]; AAM (159d. - więcej, gdyż część jest na otynkowanej wieży, 3p.). 
k. Jabłonowa ${ }^{232}$, Ostrowite k. Łasina (św. Jakuba Apostoła) ${ }^{233}$, Ostróda (św. Dominika Savio $)^{234}$, Otrów koło Sulęcina ${ }^{235}$, Ostrzeszów ${ }^{236}$, Otorowo ${ }^{237}$, Paluzy ${ }^{238}$, Papowo Toruńskie (św. Mikołaja) ${ }^{239}$, Parys (Podwyższenia Krzyża Ś ́́więtego) ${ }^{240}$, Pasłęk (św. Bartłomieja) $)^{241}$, Pasym (neogotycki) ${ }^{242}$, Pelplin ${ }^{243}$, Pelplin (katedra) ${ }^{244}$, Piaseczno ${ }^{245}$, Piotrków Trybunalski (św. Jakuba) ${ }^{246}$, Pluskowęsy (św. Jana Ewangelisty ${ }^{247}$, Pniewy ${ }^{248}$, Pobiedziska ${ }^{249}$, Postolin (św. Mikołaja) ${ }^{250}$, Poznann ${ }^{251}$,

${ }^{232}$ A. Mietz, Nowożytne graffita, dz. cyt., s. 121 - 44ś.; AAM(44d., 0p. - badania z 1996 r.).

${ }^{233} \mathrm{~K}$. Węgłowska, dz. cyt., s. 27 - 60 d., 4p.; http://www.forum.eksploracja.pl/viewtopic. $\mathrm{php} ? \mathrm{f}=142 \& \mathrm{t}=9570$ [28.11.2017].

${ }^{234} \mathrm{http}: / /$ www.forum.eksploracja.pl/viewtopic.php?f=142\&t=9570 [28.11.2017]; badania własne $-14 \mathrm{~d} ., 1 \mathrm{p}$.

${ }^{235} \mathrm{https}: / /$ czaykowska.com/2009/08/27/dziury-w-ceglach/ [28.11.2017].

${ }^{236}$ P. Mordal, dz. cyt., s. 37.

${ }^{237}$ A. Mietz, Nowożytne graffita, dz. cyt., s. 119 - 93ś.; AAM (82d., 11p. - badania z 1996 r.).

${ }^{238}$ A. Mietz, Nowożytne graffita, dz. cyt., s. 122 - 8ś.; AAM (2d., 6p. - badania z 1997 r.); badania własne $-14 \mathrm{p}$.

${ }^{239}$ A. Mietz, Nowożytne graffita, dz. cyt., s. 121 - 403ś.; J. Olędzki, dz. cyt., s. 16; K. Węgłowska, dz. cyt., s. 27 - 454 d., 32p.); AAM (361d., ponad 42p. - badania z 1995 r.); badania własne 315d.,10p.

${ }^{240}$ A. Mietz, Nowożytne graffita, dz. cyt., s. 122 -366́s.; http://www.forum.eksploracja.pl/viewtopic. php?f=142\&t=9570 [28.11.2017]; AAM (345d., 21p. - badania z 1998 r.).

${ }^{241}$ J. Hochleitner, Kubki i pręgi, dz. cyt., s. 25 - kilkanaście d.; tenże, Tajemnicze znaki na cegłach gotyckich kościołów, dz. cyt., s. 102; A. Mietz, Nowożytne graffita, dz. cyt., s. 116-381ś.; http:// www.forum.eksploracja.pl/viewtopic.php?f=142\&t=9570 [28.11.2017]; https://czaykowska. com/2009/08/27/dziury-w-ceglach/ [28.11.2017]; AAM (326d. - 25-500cm, 61p. - badania z 1996/1997 r.); badania własne - 192d., 3p.

${ }^{242}$ J. Hochleitner, Kubki i pręgi, dz. cyt., s. 27 (,jakby wyskrobany wzór”).

${ }^{243}$ A. Mietz, Nowożytne graffita, dz. cyt., s. 118 - 76ś.; badania własne (2 ś. na tzw. ,,sali kominkowej").

${ }^{244}$ AAM (72d., 4p. - badania z 1996 r.).

${ }^{245}$ A. Mietz, Nowożytne graffita, dz. cyt., s. 118 - 18ś.; AAM (18d., 0p.); badania własne - 1d.

${ }^{246} \mathrm{http}: / / w w w . s t r a z n i c y c z a s u . p l / v i e w t o p i c . p h p ? t=6630$ [28.11.2017].

${ }^{247}$ A. Mietz, Nowożytne graffita, dz. cyt., s. 121 - 14ś.; K. Węgłowska, dz. cyt., s. 27 - 26d., 3p.; AAM (9d., 5p.); badania własne - 5d.

${ }^{248}$ A. Mietz, Nowożytne graffita, dz. cyt., s. 119 - 230ś.; AAM (227d., 3p. - badania z 1996 r.).

249 J. Fogel, dz. cyt., s. 16, 17 - ok. 3200ś.; J. Kilarski, dz. cyt., s. XLIII; „,Kurier Poznański” z dnia 23 grudnia 1885 r., nr 293, s. 3 (sprawozdanie z posiedzenia sekcji archeologicznej); W. Łęcki, Szlak Piastowski, s. 33 - ponad 1000ś.; A. Mietz, Graffita czasów nowożytnych, dz. cyt., s. 47; tenże, Nowożytne graffita, dz. cyt., s. 116 - 2405ś.; P. Pilich, s. 32; I. Sołtyk, dz. cyt., s. 47; http:// pttpoz.republika.pl/promno07.htm [28.11.2017]; http://e-przewodniki.pl/przewodnik-nowy-124-rozdzial-1386.html [28.11.2017]; AAM (1880d., kilkanaście p. - 2405 ś. - badania z 1995 r.).

${ }^{250}$ Badania własne $-17 \mathrm{~d}$.

${ }^{251}$ J. Dydyński, dz. cyt., nr 294; J. Tyszkiewicz, dz. cyt., s. 594; T. Wróblewski, dz. cyt., s. 195. 
Poznań - Głuszyna ${ }^{252}$, Poznań (NMP) ${ }^{253}$, Poznań - Ostrów Tumski ${ }^{254}$, Poznań Śródka ${ }^{255}$, Prabuty (św. Wojciecha) ${ }^{256}$, Prandocin (św. Jana Chrzciciela) ${ }^{257}$, Próchnik (dzielnica Elbląga) $)^{258}$, Prusice (św. Jakuba) ${ }^{259}$, Pruszcz Gdański (Podwyższenia Krzyża Świętego ${ }^{260}$, Przeworsk (Ducha Świętego) ${ }^{261}$, Przezmark (Podwyższenia Krzyża Świętego) ${ }^{262}$, Psarskie ${ }^{263}$, Puck ${ }^{264}$, Puńsk ${ }^{265}$, Purda ${ }^{266}$, Pyrzyce (św. Maury-

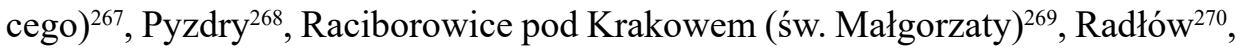

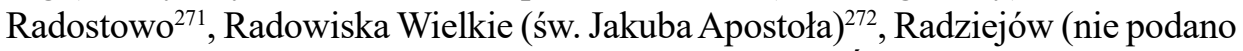
tytułu kościoła) ${ }^{273}$, Radziejów (Znalezienia Krzyża Świętego) ${ }^{274}$, Radziejów

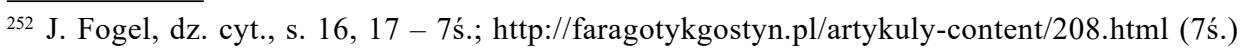
[28.11.2017].

${ }^{253}$ A. Mietz, Nowożytne graffita, dz. cyt., s. 119 - 475ś., „Kurier Poznański” 1885, s. 3 - 15ś.; AAM (liczne dołki)

${ }^{254}$ J. Fogel, dz. cyt., s. 16, 17 - 14ś.

255 Tamże, s. 16, $17-21$ ś.

${ }^{256}$ Badania własne $-4 \mathrm{~d}$.

$257 \mathrm{http}: / /$ www.straznicyczasu.pl/viewtopic.php?t=6630 [28.11.2017].

258 J. Hochleitner, Kubki i pręgi, dz. cyt., s. 25-26d., 2p.; tenże, Tajemnicze znaki na cegłach gotyckich kościołów, dz. cyt., s. 101-102-26ś.; badania własne - 18d., 1p.

${ }^{259}$ J. A. Drozdowski, dz. cyt., s. 7; https://czaykowska.com/2009/08/27/dziury-w-ceglach/ [28.11.2017].

260 A. Mietz, Nowożytne graffita, dz. cyt., s. 116 - 544ś.; I. Sołtyk, dz. cyt., s. 48; http://www.forum. eksploracja.pl/viewtopic.php?f=142\&t=9570 [28.11.2017]; https://czaykowska.com/2009/08/27/ dziury-w-ceglach/ [28.11.2017]; AAM (456d., 88p. - badania z 1998 r.); badania własne - 427d., $63 \mathrm{p}$.

${ }^{261} \mathrm{http}: / /$ www.straznicyczasu.pl/viewtopic.php?t=6630 [28.11.2017].

262 J. Hochleitner, Kubki i pręgi, dz. cyt., s. 25 - kilkanaście ś.; tenże, Tajemnicze znaki na cegłach gotyckich kościołów, dz. cyt., s. 102; J. Lewandowska, Zagadkowe ślady na murach wybranych kościołów, dz. cyt., s. 179 - 6ś.; badania własne-2d. http://www.forum.eksploracja.pl/viewtopic. php? $=142 \& \mathrm{t}=9570$ [28.11.2017].

${ }^{263}$ A. Mietz, Nowożytne graffita, dz. cyt., s. 119 - 7ś.; AAM (7d., 0p. - badania z 1996 r.).

264 A. Mietz, Nowożytne graffita, dz. cyt., s. 116 - 417ś.; AAM (d. i p. są - „dane z literatury”).

${ }^{265}$ A. Mietz, Nowożytne graffita, dz. cyt., s. 116 - 6ś.; AAM (6d. - badania z 1999 r.).

266 A. Mietz, Nowożytne graffita, dz. cyt., s. 122 - 8ś.); AAM (8d., 0p. - badania z 1996 r.).

267 A. Mietz, Nowożytne graffita, dz. cyt., s. 119 -25ś.; http://www.forum.eksploracja.pl/viewtopic. php?f=142\&t=9570 [28.11.2017]; http://architektura.pomorze.pl/?art_id=702 (30 śladów) [28.11.2017].

268 A. Mietz, Nowożytne graffita, dz. cyt., s. 123 - 219ś.; AAM (219d., 3p.).

${ }^{269} \mathrm{http}: / /$ www.straznicyczasu.pl/viewtopic.php?t=6630 [28.11.2017].

${ }^{270}$ Z. Marcinkowski, Średniowieczne dołki pokutne, „Radło”, 2011, nr V, s. 16.

${ }^{271}$ A. Mietz, Nowożytne graffita, dz. cyt., s. 122 - 15ś.; AAM (15d., 0p. - badania z 1996 r.); badania własne $-11 \mathrm{~d}$.

${ }^{272}$ A. Mietz, Nowożytne graffita, dz. cyt., s. 121 - 10ś.; K. Węgłowska, dz. cyt., s. 27 - 3d., 2p.; AAM (10d., 0p. - badania z 1996 r.).

273 A. Mietz, J. Pakulski, dz. cyt., s. 29.

${ }^{274}$ A. Mietz, Nowożytne graffita, dz. cyt., s. 123 - 117ś.; AAM (117d., kilka p. - badania z 1995 r.); badania własne $-31 \mathrm{~d}$. 
(Wniebowzięcia NMP) ${ }^{275}$, Radziki Duże ${ }^{276}$, Radzyń Chełmiński (św. Anny) $)^{277}$, Radzyń Chełmiński (św. Jerzego) ${ }^{278}$, Rakowiec k. Kwidzyna (św. Antoniego) $)^{279}$, Recz (Chrystusa Króla) ${ }^{280}$, Reszel (św.św. Piotra i Pawła) ${ }^{281}$, Rogoźno ${ }^{282}$, Rogóźno $^{283}$, Rokicie $^{284}$, Ruda k. Wielunia ${ }^{285}$, Rudawa (Wszystkich Świętych) ${ }^{286}$, Rusocice ${ }^{287}$, Rypin $^{288}$, Sampława (św. Bartłomieja) ${ }^{289}$, Sandomierz (św. Jakuba) ${ }^{290}$, Sątoczno (Chrystusa Króla) ${ }^{291}$, Sępopol ${ }^{292}$, Sieradz (św. Stanisława, kościół podominikań-

275 A. Mietz, Nowożytne graffita, dz. cyt., s. 123 - 61ś.; AAM (61d., p. są - badania z 1995 r.); badania własne $-18 \mathrm{~d}$.

${ }^{276}$ A. Mietz, Apotropaiony antydemoniczne, dz. cyt., s. 92, s. 95 - 14ś.; tenże, Nowożytne graffita, dz. cyt., s. 118 - 14ś.; AAM (14d., 0p. - ściany były szlifowane).

277 A. Mietz, Graffita czasów nowożytnych, dz. cyt., s. 47 - 240ś.; tenże, Nowożytne graffita, dz. cyt., s. 121 - 258ś.; K. Węgłowska, dz. cyt., s. $27-362$ d., 12p.; badania własne - 242d.

${ }^{278}$ K. Węgłowska, dz. cyt., s. 27 - 20d., 1p.; badania własne - 9d.

279 A. Mietz, Nowożytne graffita, dz. cyt., s.116-129ś.; http://www.forum.eksploracja.pl/viewtopic. php? $\mathrm{f}=142 \& \mathrm{t}=9570$ [28.11.2017]; badania własne $-222 \mathrm{~d}$., 2p.

280 A. Mietz, Nowożytne graffita, dz. cyt., s. 119 -24ś.; http://www.forum.eksploracja.pl/viewtopic. $\mathrm{php} ? \mathrm{f}=142 \& \mathrm{t}=9570$ [28.11.2017].

${ }^{281}$ J. Hochleitner, Kubki i pręgi, dz. cyt., s. 27 - 44d., 8p.; tenże, Tajemnicze znaki na cegłach gotyckich kościołów, dz. cyt., s. 101 - 44ś.; A. Mietz, Nowożytne graffita, dz. cyt., s. 122 - 43ś.; http://www.forum.eksploracja.pl/viewtopic.php?f=142\&t=9570\&start=140 [28.11.2017]; https:// czaykowska.com/2009/08/27/dziury-w-ceglach/ [28.11.2017]; badania własne - 27d.

${ }^{282}$ J. Dydyński, dz. cyt., nr 294; J. Fogel, dz. cyt., s. 16; H. Hockenbeck, dz. cyt., s. 118 - 308ś.; A. Mietz, dz. cyt., s. 119 -308ś..; J. Tyszkiewicz, dz. cyt., s. 594; T. Wróblewski, dz. cyt., s. 195.

${ }^{283}$ A. Mietz, Graffita czasów nowożytnych, dz. cyt., s. 47 - 8ś.; AAM (8d., 0p. - badania z 1997 r.).

${ }^{284}$ H. Horodyska-Gadkowska, ,Kobyli” kościót w Rokiciu, „Notatki Płockie”, 1968, nr V/XLIX, s. 18 („,duża liczba otworów”); A. Mietz, Apotropaiony antydemoniczne, dz. cyt., s. 92, s. 95 597ś.; Idem, Nowożytne graffita, dz. cyt., s. 118 - 597ś.; J. Olędzki, dz. cyt., s. 13;.; http://www. tp.com.pl/turystyka/pelne-tajemnic-zachodnie-rubieze-mazowsza.html [28.11.2017]; http:// kultura.wiara.pl/doc/942922.Znaki-na-kosciele [28.11.2017]; AAM (579d., 18p.).

${ }^{285}$ J. Fogel 1996, dz. cyt., s. 17; http://www.forum.eksploracja.pl/viewtopic.php?f=142\&t=9570\&si$\mathrm{d}=97 \mathrm{e} 7 \mathrm{~b} 0 \mathrm{dd} 35 \mathrm{~b} 8 \mathrm{fda} 5 \mathrm{cbb} 58 \mathrm{~d} 24 \mathrm{a} 2986 \mathrm{~d} 23 \&$ start=20 [28.11.1017]; https://czaykowska. com/2009/08/27/dziury-w-ceglach/ [28.11.2017].

${ }^{286}$ Cz. Hadamik, dz. cyt., s. 29; http://www.straznicyczasu.pl/viewtopic.php?t=6630 [28.11.2017].

${ }^{287}$ A. Mietz, Nowożytne graffita, dz. cyt., s. 123 - 19ś.; AAM (19d., 0p. - badania z 1987 r.).

288 A. Mietz, Apotropaiony antydemoniczne, dz. cyt., s. 91-92, 95 - 411ś.; tenże, Dawne inskrypcje i znaki symboliczne w farze rypińskiej. W kręgu kultury staropolskiej, w: Rypin. Szkice z dziejów miasta, red. M. Krajewski, Rypin 1994, s. 100; tenże, Nowożytne graffita, dz. cyt., s. 118 -411ś.; https://czaykowska.com/2009/08/27/dziury-w-ceglach/ [28.11.2017]; AAM (385d., 26p.).

289 J. Lewandowska, Zagadkowe ślady na murach wybranych kościołów, dz. cyt., s. 179 - 34ś.; A. Mietz, Nowożytne graffita, dz. cyt., s. 121 - 8ś.; K. Węgłowska, dz. cyt., s. 27 - 53d.; AAM (5d., 3p. - badania z 1996 r.); badania własne - 42d.

${ }^{290}$ AAM (d. są).

${ }^{291}$ A. Mietz, Nowożytne graffita, dz. cyt., s. 122 - 88ś.; M. Kwiatkowski, Dołki pokutne z Sątoczna, „Twoja Gmina Korsze”, 2016, nr X, s. 7; http://www.forum.eksploracja.pl/viewtopic. php?f=142\&t=9570 [28.11.2017]; AAM (81d., 7p. - badania z 1998 r.).

292 A. Mietz, Nowożytne graffita, dz. cyt., s. 122 - 320ś.; AAM (291d., 28p. - badania z 1997 r.). 
ski) ${ }^{293}$, Sieradz (Wszystkich Świętych, fara) ${ }^{294}$, Sierpc (św. Wita) ${ }^{295}$, Skalbmierz (św. Jana Chrzciciela) ${ }^{296}$, Skarszewy ${ }^{297}$, Skokii ${ }^{298}$, Skwierzyna ${ }^{299}$, Sławków (Podwyższenia Krzyża Świętego) ${ }^{300}$, Słupca ${ }^{301}$, Słupsk ${ }^{302}$, Sobocisko (Wniebowzięcia $\mathrm{NMP}^{303}$, Sokolica ${ }^{304}$, Srokowo (Krzyża Świętego) ${ }^{305}$, Stara Kościelnica ${ }^{306}$, Stargard Szczeciński ${ }^{307}$, Starogard Gdański (św. Mateusza) ${ }^{308}$, Stary Gostyń ${ }^{309}$, Stary Korczyn $^{310}$, Stary Targ ${ }^{311}$, Stawiszyn ${ }^{312}$, Steblewo (ruiny) ${ }^{313}$, Stopnica ${ }^{314}$, Strońsko

${ }^{293}$ J. Fogel, dz. cyt., s. 17; A. Ruszkowski, Tajemnice średniowiecznych murów, „Gościniec”, 1980, R. XII, nr IX(CXXXV), s. 23; AAM (d. są).

${ }^{294}$ A. Ruszkowski, Tajemnice, dz. cyt., s. 23; AAM (d. są).

${ }^{295}$ A. Mietz, Nowożytne graffita, dz. cyt., s. 118 - 20ś.); AAM (20d., 0p. - badania z 1996 r.).

${ }^{296} \mathrm{http}: / /$ www.straznicyczasu.pl/viewtopic.php?t=6630 [28.11.2017].

${ }^{297}$ W. Brzoskowski, Dzieje Skarszew, dz. cyt., s. 50; J. Hochleitner, Kubki i pręgi, dz. cyt., s. 26 98d., 25p.; A. Mietz, Nowożytne graffita, dz. cyt., s. 118 - 175ś.; AAM (146d., 29p. - badania z 1998 r.); badania własne - 134d., 34p.

298 J. Dydyński, dz. cyt., nr 294.

299 A. Mietz, Nowożytne graffita, dz. cyt., s. 123 - 55ś.; AAM (55d., 0p. - badania z 1996 r.).

${ }^{300}$ D. Skonieczna-Gawlik, dz. cyt., s. 230-231; https://czaykowska.com/2009/08/27/dziury-w-ceglach/ [28.11.2017]; http://www.straznicyczasu.pl/viewtopic.php?t=6630 [28.11.2017].

301 A. Mietz, Nowożytne graffita, dz. cyt., s. 116 - 123ś.; AAM (123d., 0p. - badania z 1996 r.).

${ }^{302}$ A. Mietz, Nowożytne graffita, dz. cyt., s. 117; J. Olędzki, dz. cyt., s. 13; AAM (podominikański, św. Jacka - 63d. przy wejściu i liczne na nawie prawej).

${ }^{303} \mathrm{http} / / /$ www.forum.eksploracja.pl/viewtopic.php?f=142\&t=9570 [28.11.2017] - (ok.50d.); https:// czaykowska.com/2009/08/27/dziury-w-ceglach/ [28.11.2017].

${ }^{304}$ A. Mietz, Nowożytne graffita, dz. cyt., s. 122 - 23ś.; AAM (18d., 5p. - badania z 1997 r.).

${ }^{305}$ A. Mietz, Nowożytne graffita, dz. cyt., s. 122 - 27ś.; http://www.forum.eksploracja.pl/viewtopic. php? $=142 \& \mathrm{t}=9570$ [28.11.2017].

306 S. Pauch, Wybrane przejawy, dz. cyt., s. 206 - 19ś.; badania własne - 19ś.

307 J. Fogel, dz. cyt., s. 17; A. Mietz, Nowożytne graffita, dz. cyt., s. 119; M. Ober, Stargard Szczeciński - kościót NPMarii, „Spotkania z Zabytkami”, 1982, nr IX, s. 52-54; AAM (są wg literatury).

${ }^{308}$ W. Brzoskowski, Dzieje Skarszew, dz. cyt., s. 50; A. Mietz, Nowożytne graffita, dz. cyt., s. 118 - 84ś.; http://www.forum.eksploracja.pl/viewtopic.php?f=142\&t=9570 [28.11.2017]; https:// czaykowska.com/2009/08/27/dziury-w-ceglach/ [28.11.2017]; badania własne - 217d., 19p.

309 J. Kilarski, dz. cyt., s. 207; A. Mietz, Nowożytne graffita, dz. cyt., s. 119 - 56ś.; AAM (56d., 0p. - badania z 1996 r.).

${ }^{310}$ W kamiennym fundamencie wieży kościelnej z 1920 r. - www.straznicyczasu.pl [16.08.2018].

311 J. Hochleitner, Kubki i pręgi, dz. cyt., s. 25 - 70d., 20p.; tenże, Tajemnicze znaki na cegłach gotyckich kościołów, dz. cyt., s. 102 - 70 ś.; A. Mietz, Nowożytne graffita, dz. cyt., s. 116-71́́.; badania własne - 80d., 20p.

312 A. Mietz, Nowożytne graffita, dz. cyt., s. 117 - 252ś.; AAM (252d., 0p.).

313 A. Mietz, Nowożytne graffita, dz. cyt., s. 116 - 41ś.; http://www.forum.eksploracja.pl/viewtopic. php?f=142\&t=9570 [28.11.2017]; https://czaykowska.com/2009/08/27/dziury-w-ceglach/ [28.11.2017]; AAM (33d., 8p. - badania z 1998 r.); badania własne - 67d., 6p.

$314 \mathrm{http}: / /$ www.straznicyczasu.pl/viewtopic.php?f=57\&t=6630\&sid=c96ff46f893ce1470867fc6e06436849\&start $=30$ [1.08.2018]. 
(św. Urszuli) $)^{315}$, Strzelin (św. Gotarda) ${ }^{316}$, Strzelno (św. Prokopa) ${ }^{317}$, Strzelno (św. Trójcy) $)^{318}$, Subkowy (św. Stanisława) ${ }^{319}$, Suchy Dąb (św.św. Anny i Joachima) ${ }^{320}$, Susz $^{321}$, Szadek ${ }^{322}$, Szamotuły (pw. MB Pocieszenia i św. Stanisława) $)^{323}$, Sząbruk ${ }^{324}$, Szczecin (św. Jakuba) ${ }^{325}$, Szczepanki k. Łasina (św. Wawrzyńca) $)^{326}$, Szczytno (neogotyk) ${ }^{327}$, Szubin ${ }^{328}$, Szydłów (św. Władysława) ${ }^{32}$, Szydłów (Wszystkich Świętych ${ }^{330}$, Śmigiel ${ }^{331}$, Śrem ${ }^{332}$, Środa [Wielkopolska] ${ }^{333}$, Świebodzin ${ }^{334}$, Tarczyn (św. Mikołaja) ${ }^{335}$, Tczew (fara) ${ }^{336}$, Tczew (św. Stanisława Kostki) ${ }^{337}$,

315 J. Fogel, dz. cyt., s. 17; A. Ruszkowski, Tajemnice, dz. cyt., s. 23 (kilkadziesiąt wgłębień); A. Mietz, Nowożytne graffita, dz. cyt., s. 117 (166́s.); http://www.forum.eksploracja.pl/viewtopic. php?f=142\&t=9570 [28.11.2017]; AAM (161d., 5p. - badania z 1999 r.).

$316 \mathrm{https}: / /$ czaykowska.com/2009/08/27/dziury-w-ceglach/ [28.11.2017].

317 A. Mietz, Nowożytne graffita, dz. cyt., s. 117 - 9ś.

318 Tenże, Zbawienie i potepienie, dz. cyt., s. 18.

319 Tenże, Nowożytne graffita, dz. cyt., s. 118 - 25ś.; I. Sołtyk, dz. cyt., s. 47; AAM (13d., 9p. badania z 1996 r.); badania własne - 3d.

${ }^{320}$ Badania własne - 10d.

${ }^{321}$ J. Lewandowska, Zagadkowe ślady na murach wybranych kościołów, dz. cyt., s. 179 - 238ś.; K. Madela, dz. cyt., s. 9; A. Mietz, Nowożytne graffita, dz. cyt., s. 116 - 62́́.; AAM (62d., 0p. badania z 1996 r.); badania własne - 212d., 9p.

322 J. Fogel, dz. cyt., s. 17; A. Mietz, Nowożytne graffita, dz. cyt., s. 123 - 31ś.; A. Ruszkowski, Tajemnice, dz. cyt., s. 23; AAM (29d., 2p. - badania z 1999 r.).

323 J. Fogel, dz. cyt., s. 16; F. Jaśkowiak, dz. cyt., s. 172; J. Kilarski, dz. cyt., s. 157; A. Mietz, dz. cyt., s. 119 - 170ś; P. Mordal, dz. cyt., s. 36 -260ś.; http://www.poboczemdrogi.pl/2016/11/szamotuy-zwiedzanie-z-duchami.html [28.11.2017]; AAM (170d. - badania z 1996 r.).

${ }^{324}$ A. Mietz, Nowożytne graffita, dz. cyt., s. 122 - 14ś.; AAM (14d., 0p. - badania z 1995 r.); badania własne $-23 \mathrm{~d}$.

${ }^{325}$ E. Friedel, Backsteine mit Näpfchen und Rillen, "Archiv für kirchliche Baukunst und Kircherschmuck”, 1877, R. II, z. IV, s. 57; A. Mietz, Nowożytne graffita, dz. cyt., s. 119; http://www. forum.eksploracja.pl/viewtopic.php?f=142\&t=9570 [28.11.2017]; http://architektura.pomorze. pl/?art_id=705 [28.11.2017]; AAM (są d. oraz p.).

${ }^{326}$ Badania własne - 76d.

${ }^{327}$ J. Hochleitner, Kubki i pręgi, dz. cyt., s. 27 (,,pseudokubki” i „pseudopręgi”).

${ }^{328}$ A. Mietz, Nowożytne graffita, dz. cyt., s. 115 - 349śs; AAM (314d., liczne p.); badania własne $-314 d ., 32 p$.

${ }^{329} \mathrm{http} / / /$ www.straznicyczasu.pl - ok. 90 śladów [16.08.2018].

${ }^{330} \mathrm{http} / / /$ www.straznicyczasu.pl/viewtopic.php? $\mathrm{f}=57 \& \mathrm{t}=6630 \&$ start $=40$ [16.08.2018].

331 A. Mietz, Nowożytne graffita, dz. cyt., s. 119 - 9ś.; AAM (9d., 0p. - badania z 1999 r.).

${ }^{332}$ J. Fogel, dz. cyt., s. 16, 17 -14ś.; http://faragotykgostyn.pl/artykuly-content/208.html [28.11.2017].

${ }^{333}$ J. Fogel, dz. cyt., s. 16; J. Kilarski, dz. cyt., s. 252; A. Mietz, Nowożytne graffita, dz. cyt., s. $119-$ 216ś; J. Tyszkiewicz, dz. cyt., s. 594; T. Wróblewski, dz. cyt., s. 195, 199 („niektóre kościoły”, kolegiata); AAM (216d., są też p. - badania z 1995 r.).

${ }_{334}$ A. Mietz, Nowożytne graffita, dz. cyt., s. 123 - 58ś.; AAM (52d., 6p. - badania z 1996 r.).

${ }^{335} \mathrm{http}: / /$ www.straznicyczasu.pl/viewtopic.php?t=6630 [28.11.2017].

336 J. Fogel, dz. cyt., s. 17; F. Jaśkowiak, dz. cyt., s. 134; A. Mietz, Nowożytne graffita, dz. cyt., s. 118 - 217ś.; K. Staszewski, dz. cyt., s. 266; https://czaykowska.com/2009/08/27/dziury-w-ceglach/ [28.11.2017]; AAM (d. są wg literatury); badania własne - 548d., 58p.

${ }^{337}$ AAM (d. są wg literatury); z badań własnych wynika, iż aktualnie nie ma śladów na tejże świątyni. 
Tłokowo ${ }^{338}$, Tolkmicko ${ }^{339}$, Tołkiny (Matki Boskiej Ostrobramskiej) ${ }^{340}$, Toruń (Najświętszej Marii Panny) $)^{341}$, Toruń (św. Jakuba) ${ }^{342}$, Toruń (św. Jana Ewangelisty i św. Jana Chrzciciela) ${ }^{343}$, Trląg ${ }^{344}$, Trutnowy ${ }^{345}$, Trzebiatów (Macierzyństwa Najświętszej Marii Panny) ${ }^{346}$, Tuczno ${ }^{347}$, Tuja (św. Jakuba) $)^{348}$, Tulce ${ }^{349}$, Tum k. Łęczycy (NMP i św. Aleksego) ${ }^{350}$, Tychnowy ${ }^{351}$, Uniejów ${ }^{352}$, Unieradz (św. Michała Archanioła) ${ }^{353}$, Urzędów ${ }^{354}$, Wawrzeńczyce (św. Zygmunta i św. Marii Magdaleny) ${ }^{355}$,

${ }^{338}$ A. Mietz, Nowożytne graffita, dz. cyt., s. 122 - 9ś.; AAM (9d. - badania z 1997 r.); badania własne - 9d.

${ }^{339}$ J. Hochleitner, Kubki i pręgi, dz. cyt., s. 25 - 27d., 17p., 5 zamurowanych; tenże, Tajemnicze znaki na cegłach gotyckich kościołów, dz. cyt., s. 102 - ponad 30ś.; A. Mietz, Nowożytne graffita, dz. cyt., s. 116 - 43ś.; badania własne -65 d., 25 p.

${ }^{340} \mathrm{http} / / /$ www.forum.eksploracja.pl/viewtopic.php? $\mathrm{f}=142 \& \mathrm{t}=9570$ [28.11.2017].

${ }^{341}$ J. Hochleitner, Kubki i pręgi, dz. cyt., s. 28 - 1ś.; K. Węgłowska, dz. cyt., s. 28 - 9d.); badania własne -2 ś.

${ }^{342}$ A. Mietz, Nowożytne graffita, dz. cyt., s. 121 - 49ś.; K. Węgłowska, dz. cyt., s. 28 - 83d., 2p.; badania własne $-69 \mathrm{~d}$.

${ }^{343}$ J. Hochleitner, Kubki i pręgi, dz. cyt., s. 28; A. Mietz, Nowożytne graffita, dz. cyt., s. 121 - 188ś.; J. Olędzki, dz. cyt., s. 13 (,pokaźna ilość jamek”); K. Węgłowska, dz. cyt., s. 28 - 476d., 3p.; http://www.forum.eksploracja.pl/viewtopic.php? $\mathrm{f}=142 \& \mathrm{t}=9570 \&$ sid $=97 \mathrm{e} 7 \mathrm{~b} 0 \mathrm{dd} 35 \mathrm{~b} 8 \mathrm{fda} 5 \mathrm{cbb}-$ 58d24a2986d23\&start=20 [28.11.2017]; badania własne -177 ś.

${ }^{344}$ A. Mietz, Nowożytne graffita, dz. cyt., s. 117 - 509ś.; http://www.forum.eksploracja.pl/viewtopic. php?f=142\&t=9570\&start=140 [28.11.207]; http://manowce.com/trlag/ [28.11.2017]; AAM (508d.,1p.); badania własne - 496d.

${ }^{345}$ A. Mietz, Nowożytne graffita, dz. cyt., s. 116-37ś.; http://www.forum.eksploracja.pl/viewtopic. php?f=142\&t=9570 [28.11.2017]; https://czaykowska.com/2009/08/27/dziury-w-ceglach/ [28.11.2017]; AAM (36d., 1p. - badania z 1998 r.); badania własne - 2d.

${ }^{346}$ T. Siemiński, ,Znaki istnienia” na kościele pod wezwaniem Macierzyństwa Najświętszej Marii Panny w Trzebiatowie, w: Trzebiatów - historia i kultura. Materialy z konferencji, Trzebiatów, 26-27 maja 2000, red. W. Łysiak, Poznań 2000, s. 141; http://www.forum.eksploracja.pl/viewtopic.php? $\mathrm{f}=142 \& \mathrm{t}=9570$ [28.11.2017].

${ }^{347}$ A. Mietz, Nowożytne graffita, dz. cyt., s. 117 - 84ś.; http://www.forum.eksploracja.pl/viewtopic. php? $\mathrm{f}=142 \& \mathrm{t}=9570 \&$ start=40 [28.11.2017]; AAM (82d., 2p. - badania z $1998 \mathrm{r}$.).

${ }^{348}$ S. Pauch, Wybrane przejawy, dz. cyt., s. 206 - 5ś.; http://www.forum.eksploracja.pl/viewtopic. php?f=142\&t=9570 [28.11.2017]; https://czaykowska.com/2009/08/27/dziury-w-ceglach/ [28.11.2017]; badania własne $-5 \mathrm{~d}$.

349 J. Fogel, dz. cyt., s. 16, 17 - 985ś.

${ }^{350}$ A. Mietz, Nowożytne graffita, dz. cyt., s. 117 - 9ś.; tenże, Zbawienie i potępienie, dz. cyt., s. 17; http://www.forum.eksploracja.pl/viewtopic.php?f=142\&t=9570 [28.11.2017]; http://meteor2017. bikestats.pl/1578128,Weekend-13ego-2-Z-Niedzieli-na-Leczyce.html [28.11.2017].

351 A. Mietz, Nowożytne graffita, dz. cyt., s. 117 - 18ś.; badania własne - 2d.

352 A. Mietz, Nowożytne graffita, dz. cyt., s. 123 - 126ś.; AAM (126d., 0p. - badania z 1997 r.).

${ }^{353} \mathrm{http}: / / \mathrm{www}$. forum.eksploracja.pl/viewtopic.php? $\mathrm{f}=142 \& \mathrm{t}=9570$ [28.11.2017].

${ }^{354} \mathrm{http} / /$ www.forum.eksploracja.pl/viewtopic.php? $\mathrm{f}=142 \& \mathrm{t}=9570 \&$ start=60 [28.11.2017]; http:// gokurzedow.pl/u/gzu07/016.htm [28.11.2017].

$355 \mathrm{http}: / /$ www.straznicyczasu.pl/viewtopic.php?t=6630 [28.11.2017]. 
Wągrowiec ${ }^{356}$, Wąsosz ${ }^{357}$, Wejherowo ${ }^{358}$, Wielki Garc ${ }^{359}$, Wieluń (kościół Bożego Ciała) ${ }^{360}$, Wierzbna ${ }^{361}$, Wilczyn ${ }^{362}$, Wilczyna ${ }^{363}$, Witków k. Szprotawy ${ }^{364}$, Włocławek (św. Witalisa) ${ }^{365}$, Wocławy ${ }^{366}$, Wrocki (św. Marcina) $)^{367}$, Wronki ${ }^{368}$, Września ${ }^{369}$, Wysiołek Luborzycki (Podwyższenia Krzyża Świętego) ${ }^{370}$, Wysocice ${ }^{371}$, Wysocko ${ }^{372}$, Wyszogród (kościół franciszkanów) ${ }^{373}$, Zalewo (św.św. Jana Apostoła i Ewangelisty) ${ }^{374}$, Zator (św.św. Wojciecha i Jerzego) ${ }^{375}$, Zbarzewo ${ }^{376}$, Zgłowiączka ${ }^{377}$,

356 J. Dydyński, dz. cyt., nr 294; J. Fogel, dz. cyt., s. 16; J. Hochleitner, Tajemnicze znaki na cegłach gotyckich kościołów, dz. cyt., s. 101 -820ś.; H. Hockenbeck, dz. cyt., s. 118 -820ś.; F. Jaśkowiak, dz. cyt., s. 192 - 552ś.; J. Kilarski, dz. cyt., s. 106; A. Mietz, Nowożytne graffita, dz. cyt., s. 117 835ś.; J. Tyszkiewicz, dz. cyt., s. 594; T. Wróblewski, dz. cyt., s. 195; AAM (820d., są p. - badania z 1995 r.); badania własne - 569d., 8p.

357 A. Mietz, Nowożytne graffita, dz. cyt., s. 117 - 32ś.

358 Tamże, s. 116 - 3ś.; AAM (2d., 2p.).

359 A. Mietz, Nowożytne graffita, dz. cyt., s. 118 -11ś.; I. Sołtyk, dz. cyt., s. 51 - 11d.; AAM (8d., 3p.).

360 J.A. Drozdowski, dz. cyt., s. 7; M. Hellmich, dz. cyt., s. 79.

361 J. Pilch, Zabytki architektury Dolnego Ślaska, Wrocław-Warszawa-Kraków-Gdańsk 1978, s. 290-291; AAM (są d. i p. wg literatury).

${ }^{362}$ A. Mietz, Nowożytne graffita, dz. cyt., s. 117 - 2ś.; AAM (2d., 0p. - badania z 1996 r.).

${ }^{363}$ A. Mietz, Nowożytne graffita, s. 119 - 2ś.

${ }^{364}$ J.A. Drozdowski, dz. cyt., s. 4, 6.

${ }^{365}$ Badania własne - 3d.

$366 \mathrm{http}: / /$ www.forum.eksploracja.pl/viewtopic.php?f=142\&t=9570 [28.11.2017]; https://czaykowska. com/2009/08/27/dziury-w-ceglach/ [28.11.2017].

367 A. Mietz, Nowożytne graffita, dz. cyt., s. 121 - 16ś.; K. Węgłowska, dz. cyt., s. 28 - 4d.; AAM (14d, 2p. - badania z 1999 r.); badania własne - 5d.

368 A. Mietz, Nowożytne graffita, dz. cyt., s. 119 - 16ś.; AAM (11d., 5p. - badania z 1996 r.).

369 J. Hochleitner, Tajemnicze znaki na cegłach gotyckich kościołów, dz. cyt., s. 101 - 800ś.; F. Jaśkowiak, dz. cyt., s. 135 - 800ś.; J. Kilarski, dz. cyt., s. 280; A. Mietz, Nowożytne graffita, dz. cyt., s. 117 - 714ś.; AAM (114d.).

${ }^{370} \mathrm{http}: / /$ www.straznicyczasu.pl/viewtopic.php?t=6630 [28.11.2017.

${ }^{371}$ Tamże

372 J. Dydyński, dz. cyt., nr 293; J. Fogel, dz. cyt., s. 16; T. Lisiewicz, dz. cyt., s. 157; A. Mietz, Nowożytne graffita, dz. cyt., s. 117 - 458ś.; J. Tyszkiewicz, dz. cyt., s. 594; T. Wróblewski, dz. cyt., s. 195, 201; https://naszaprawdablog.wordpress.com/2016/11/27/tajemnicze-dolki-na-murach-kosciola-w-wysocku/ [28.11.2017]; AAM (442d., 36p. - badania z 1996 r.).

373 A. Mietz, Nowożytne graffita, dz. cyt., s. 118 -23ś.; J. Olędzki, dz. cyt., s. 15; AAM (23d. - badania z 1998 r.).

${ }^{374}$ J. Lewandowska, Zagadkowe ślady na murach wybranych kościołów, dz. cyt., s. 179 - 27ś.; K. Madela, dz. cyt., s. 9, 12 (baszta średniowieczna); http://www.forum.eksploracja.pl/viewtopic. php?f=142\&t=9570 [28.11.2017]; https://czaykowska.com/2009/08/27/dziury-w-ceglach/ [28.11.2017]; badania własne - 64d., 3p.

$375 \mathrm{http}: / /$ www.straznicyczasu.pl/viewtopic.php?t=6630 [28.11.2017]; http://www.forum.eksploracja. pl/viewtopic.php? $\mathrm{f}=142 \& \mathrm{t}=9570$ [28.11.2017].

376 A. Mietz, Nowożytne graffita, dz. cyt., s. 119 - 5ś.; AAM (5p. - badania z 1996 r.).

377 Badania własne - 10d. 
Zieleń (św.św. Piotra i Pawła) ${ }^{378}$, Żagań (kościół gimnazjalny) ${ }^{379}$, Żarnowiec (Narodzenia Najświętszej Maryi Panny, pow. zawierciański) ${ }^{380}$, Żarnów ${ }^{381}$, Żary ${ }^{382}$, Żmijewo ${ }^{383}$, Żnin (św. Floriana) ${ }^{384}$, Żory (św. Filipa i Jakuba) ${ }^{385}$.

Tak ujęta problematyka śladów dołkowych pozwala na przeprowadzenie dalszych badań nad tymi zagadkowymi otworami, w odniesieniu do innych rejonów kraju. Badacze mają możliwość porównania wyników własnych badań z osiągniętymi przez osoby, których prace zacytowano w przypisach do niniejszego artykułu. Zauważalne jest także, iż dołki występują w dużej liczbie na obszarze Polski północnej - wzdłuż Dolnej Wisły i na wschód od jej linii (Powiśle, Warmia, Mazury, ziemia chełmińska, ziemia lubawska). Można dostrzec je również na świątyniach Kujaw, a także na Pomorzu Gdańskim. Są też charakterystyczne dla obszaru Wielkopolski, częściowo Małopolski, kieleckiego, części Mazowsza, a także obszarów przygranicznych na zachodzie kraju. Na południu Polski występują wyspowo.

Nasuwa się także wniosek, iż z racji malejącej liczby śladów (wynika to np. z faktu odnotowywania coraz mniejszej liczby śladów przez kolejnych inwentaryzatorów podejmujących się policzenia śladów, np. w Chojnicach) zasadne jest tworzenie analogicznych katalogów w przyszłości.

\section{Bibliografia}

AAM (Archiwum Andrzeja Mietza) - w zbiorach rodziny tego autora, fotokopie w zbiorach autora niniejszego artykułu.

Brzoskowski W., Dzieje Skarszew, Skarszewy 2009.

Chrzanowski T., Kornecki T., Sztuka Ziemi Krakowskiej, Kraków 1982.

Drozdowski J.A., Kubki, pręgi..., „Przydrożne Pomniki Przeszłości”, 1986, z. 2, s. 2-7.

Dydyński J., Uwagi o wklęstościach kulistych na murze kościelnym, „Kurier Poznański”, 1885, nr 293-296.

Fogel J., Frapujaca zagadka średniowiecznych światyń, „Przegląd Wielkopolski”, 1996, nr 35-36, s. 15-20.

\footnotetext{
${ }^{378}$ K. Węgłowska, dz. cyt., s. $28-1$ d.

379 J. A. Drozdowski, dz. cyt., s. 4.

$380 \mathrm{http}: / /$ www.straznicyczasu.pl/viewtopic.php?t=6630 [28.11.2017]; AAM (są d.).

${ }^{381}$ J. Fogel, dz. cyt., s. 17; M. P. Pilichowie, Ziemia kielecka, Warszawa 1979, s. 208.

382 J. Fogel, dz. cyt., s. 17 - 158ś.; http://faragotykgostyn.pl/artykuly-content/208.html [28.11.2017].

383 A. Mietz, Nowożytne graffita, dz. cyt., s. 121 - 5ś.; AAM (3d., 2p. - badania z 1996 r.).

${ }^{384}$ Badania własne - 6d.; AAM (5d.).

$385 \mathrm{http}: / /$ www.straznicyczasu.pl/viewtopic.php?t=6630 [28.11.2017].
} 
Friedel E., Backsteine mit Näpfchen und Rillen, "Archiv für kirchliche Baukunst und Kircherschmuck", 1877, R. 2, z. 4, s. 56-58.

Grempler G., Ueber Altertümliches in Bunzlau, "Jahresbericht der Schlesischen Gesellschaft für vaterländische Cultur”, 1893, s. 53-55.

Hadamik Cz., Moskorzew i jego zabytki, ,Ziemia Częstochowska”, T. XXXVI, s. 29.

Hellmich M., Nochmals die Teufelskrallen und Näpfchen an alten Bauwerken, "Korrespondenzblatt des Gesamtvereins der Deutschen Geschichts - und Altertumsvereine", 1918, nr 3/4, s. 71-79.

Hochleitner J., Kubki i pręgi na krzyżackich kościołach, „Przydrożne Pomniki Przeszłości”, 1993, z. 16, s. 24-28.

Hochleitner J., Tajemnicze znaki na cegłach gotyckich kościołów na przykładzie katedry św. Mikołaja w Elbląu, ,Rocznik Elbląski”, 2002, t. XVIII, s. 95-102.

Hockenbeck H., Die Näpfchensteine an den Pfarrkirchen zu Klecko, Lekno, Rogasen und Wongrowitz, "Zeitschrift der Historischen Gesellschaft für die Provinz Posen", 1885, t. 1, s. 118-133.

Horodyska-Gadkowska H., ,Kobyli” kościół w Rokiciu, „Notatki Płockie”, 1968, nr 5/49, s. 18-19.

Jaśkowiak F., Okolice Poznania, Wydawnictwo Poznańskie, Poznań 1972.

Kamińska K., Zagłębienia na cegłach z chojnickiej bazyliki, „Baszta”, 2011, t. 11 , s. 37-43.

Kilarski J., Przewodnik po Wielkopolsce, Nakładem Księgarni św. Wojciecha, Poznań-Warszawa-Wilno-Lublin 1938.

Lewandowska J., Zagadkowe ślady na murach kościołów w Brodnicy, Lembargu, Lubawie i Nowym Mieście Lubawskim, w: Wiara z demonem w tle. Studia nad materialnymi śladami przekazu informacji na ziemiach polskich do schytku XVIII wieku, Wydawnictwo Adam Marszałek, Toruń 2008, s. 57-76.

Kurier Poznański, Kurier Poznański z dnia 23 grudnia 1885 r., 293 numer, s. 3 (sprawozdanie z posiedzenia sekcji archeologicznej) - anonimowy autor.

Kwiatkowski M., Dołki pokutne z Sątoczna, „Twoja Gmina Korsze”, 2016, nr 10 , s. 7.

Lewandowska J., Zagadkowe ślady na murach wybranych kościołów w Polsce północno-wschodniej, w: Zjawiska magiczno-demoniczne na terenie dawnych ziem pruskich na tle porównawczym, red. K. Grążawski, J. Gancewski, Wydawnictwo Uniwersytetu Warmińsko-Mazurskiego, Olsztyn 2014, s. 177-189.

Lisiewicz T., W sprawie kamieni ze śladami, „Światowit”, 1902, t. IV, s. $157-160$.

Łęcki W., Szlak Piastowski, Wydawnictwo Wojewódzkiej Biblioteki Publicznej i Centrum Animacji Kultury, Poznań 2006.

Madela K., Tajemnicze znaki na cegłach kościoła św. Antoniego w Suszu, „Skarbiec Suski. Historia, środowisko, kultura”, 2009, nr 1, s. 9-14. 
Marcinkowski Z., Średniowieczne dołki pokutne, „Radło”, 2011, nr 5, s. 16.

Mietz A., Apotropaiony antydemoniczne na światyniach ziemi dobrzyńskiej, „Rocznik Muzeum Ziemi Dobrzyńskiej w Rypinie”, t. I, s. 89-96.

Mietz A., Dawne inskrypcje i znaki symboliczne w farze rypińskiej. W kręgu kultury staropolskiej, w: Rypin. Szkice z dziejów miasta, red. M. Krajewski, Dobrzyński Oddział Włocławskiego Towarzystwa Naukowego w Rypinie, Rypin 1994, s. 93-104.

A. Mietz, Graffita czasów nowożytnych na murach kościołów w Grudziądzu i okolicy. Tożsamość - orędownictwo - zbawienie, „Rocznik Grudziądzki”, 1998, t. XIII, s. 33-47.

Mietz A., Nowożytne graffita i ślady oczyszczania ogniem w Polsce Środkowej i Pólnocnej, w: Wiara z demonem w tle. Studia nad materialnymi śladami przekazu informacji na ziemiach polskich do schytku XVIII wieku, Wydawnictwo Adam Marszałek, Toruń 2008, s. 79-135.

Mietz A., Zbawienie i potepienie w świadectwach nowożytnych graffiti. Ze studiów nad staropolska religijnościa masowa poludniowego pogranicza kujawsko-wielkopolskiego, w: Studia z dziejów potudniowego pogranicza kujawsko-wielkopolskiego, red. P. Szczepankiewicz, Wydawnictwo Propaganda, Włocławek-Wierzbinek 2010, s. 11-19.

Mietz A., Pakulski J., Corpus Inscriptionum Poloniae, t. IV (Kujawy brzeskie), Muzeum Ziemi Kujawskiej i Dobrzyńskiej we Włocławku, Włocławek-Toruń 1985.

Mordal P., Kubki i rysy na ścianach kościoła w Szamotułach, „Przydrożne Pomniki Przeszłości”, 1990, z. 11, s. 36-37.

Mróz H., Graffiti czasów nowożytnych na murach kościoła w Górze koło Żnina, w: Studia z dziejów poludniowego pogranicza kujawsko-wielkopolskiego, red. P. Szczepankiewicz, Wydawnictwo Propaganda, Włocławek-Wierzbinek 2010, s. 20-27.

Ober M., Stargard Szczeciński - kościót NPMarii, „Spotkania z Zabytkami”, 1982, nr 9, s. 52-54.

Olędzki J., Znaki istnienia, „Polska Sztuka Ludowa”, 1985, R. XXXIX, nr 1-2, s. $3-21$.

Pauch S., Dolki pokutne w tasinie, „Prowincja”, 2012, nr 1(7), s. 77-82.

Pauch, Ślady dołkowe na murach kościołów gotyckich na terenie wybranych diecezji Polski pótnocnej (praca doktorska w zbiorach UKW w Bydgoszczy), Bydgoszcz 2018.

Pauch S., Ślady na murach bazyliki pw. Ścięcia św. Jana Chrzciciela w Chojnicach, „Zeszyty Chojnickie”, 2015, nr 31, s. 62-67.

Pauch S., Ślady na murach kościoła św. Mikołaja w Gniewie, jako wyraz lęku przed nagła śmiercia, ,Nasza Przeszłość”, 2016, t. 125, s. 165-182. 
Pauch S., Wybrane przejawy religijności na murach budowli sakralnych Wielkich Żuław Malborskich, „Studia Pelplińskie”, 2015, t. XLVIII, s. 203-211.

Pęcherski Z., Konin - Kolo - Turek. Przewodnik wycieczkowy, Wydawnictwo Poznańskie, Poznań 1966.

Pilch J., Zabytki architektury Dolnego Ślaska, Wydawnictwo Ossolineum, Wrocław-Warszawa-Kraków-Gdańsk 1978.

Pilich P., Jeszcze raz o ,, dołkach wierconych ”, ,Przydrożne Pomniki Przeszłości”, 1990, nr 11, s. 32-35.

Pilichowie M., P., Ziemia kielecka, Krajowa Agencja Wydawnicza, Warszawa 1979.

Ruszkowski A., Ślady po nieceniu ognia na murach kościołów województwa sieradzkiego, „Biuletyn ZW PTTK”, 1980, nr 2(272), s. 17-19.

Ruszkowski A., Tajemnice średniowiecznych murów, „Gościniec”, 1980, R. XII, nr 9(135), s. 23.

Schels P., Schabespuren auf Stein (Rillen und Näpfchen) - http://www.yumpu. $\mathrm{com} / \mathrm{de} /$ document/view/8703752/schabespuren-auf-stein-rillen-und-napfchenhosting-agency [15.12.2019].

Siemiński T., „Znaki istnienia” na kościele pod wezwaniem Macierzyństwa Najświętszej Marii Panny w Trzebiatowie, w: Trzebiatów - historia i kultura. Materiaty z konferencji, Trzebiatów, 26-27 maja 2000, red. W. Łysiak, Wydawnictwo Eco, Poznań 2000.

Skonieczna-Gawlik D., Tropem badaczy Zagłębia Dąbrowskiego, Regionalny Instytut Kultury w Katowicach, Katowice 2016.

Sołtyk I., Graffiti czasów nowożytnych na murach Bazyliki pod wezwaniem Ścięcia św. Jana Chrzciciela w Chojnicach. Studium analityczne, Przedsiębiorstwo Marketingowe Logo, Chojnice 2011.

Staszewski K., Tajemnica ,wierconych dołków”, „Ziemia” 1966, s. 265-266.

Szczepański P., Kubki i pręgi na kościele św. Mikołaja w Elblagu, „Przydrożne Pomniki Przeszłości”, 1993, z. 16, s. 28-29.

Tyszkiewicz J., ,, Nowy ogień” "na wiosnę, w: Cultus et cognitio. Studia z dziejów średniowiecznej kultury, Państwowe Wydawnictwo Naukowe, Warszawa 1976, s. 591-597.

Weertz J., Weertz E., Duffin Ch.J., Possible sources of therapeutic stone powder from North West Europe, "Pharmaceutical Historian", 2014, t. 44, nr 2, s. 27-32.

Węgłowska K., Nieckowate zagłębienia na elewacjach średniowiecznych obiektów sakralnych na obszarze ziemi chetmińskiej i lubawskiej (praca doktorska w zbiorach UMK w Toruniu), Torun 2016.

Wróblewski T., Zagadkowe ślady na ścianach kościołów w Wielkopolsce, „Studia i Materiały do Dziejów Wielkopolski i Pomorza”, 1958, t. IV, z. 2, s. 195-205. 
Źródła internetowe

http://architektura.pomorze.pl/?art_id=892

http://czaykowska.com/2009/08/27/dziury-w-ceglach/

http://e-przewodniki.pl/przewodnik-nowy-124-rozdzial-1386.html

http://em.kielce.pl/publicystyka/w-imie-boga

http://faragotykgostyn.pl/artykuly-content/208.html

http://gokurzedow.pl/u/gzu07/016.htm

http://manowce.com/trlag/

http://meteor2017.bikestats.p1/1578128, Weekend-13ego-2-Z-Niedzieli-na-Leczyce.html

https://naszaprawdablog.wordpress.com/2016/11/27/tajemnicze-dolki-na-murach-kosciola-w-wysocku/

http://pttpoz.republika.pl/promno07.htm

http://silesion.pl/najszczesliwsze-miasto-na-swiecie-02-07-2017

http://tomi.blox.pl/2010/06/Cegly-kosciola-w-Kozlowie-Biskupim.html

http://webcache.googleusercontent.com/search?q=cache:http://meteor2017. bikestats.pl/1578125, Weekend-13ego-1-Z-Soboty-na-Piatek.html\&gws_rd=cr\&dcr=0\&ei=-li1 WZjiM6qg6ASjr4foDQ

http://wikimapia.org/36212396/pl/Do\%C5\%82ki-pokutne

http://www.czasbrodnicy.pl/czasbrodnicy/1,93191,22518255,skad-sie-wziely-dziury-w-farze.html

http://www.czasbrodnicy.pl/czasbrodnicy/1,93191,12040429,Tajemnicze_ znaki_na_farze.html

http://www.forum.eksploracja.pl/viewtopic.php?f=142\&t=9570

http://www.graudenz.pl/ciekawostki/graffiti-na-murach-kosciola-sw-mikolaja/ http://www.krajoznawcy.info.pl/znaki-pokuty-i-dobrych-interesow-8315

http://kultura.wiara.pl/doc/942922.Znaki-na-kosciele

https://www.lm.pl/aktualnosci/informacja/57627/W-trosce-o-zabytki

http://www.poboczemdrogi.p1/2016/11/szamotuy-zwiedzanie-z-duchami.html http://www.straznicyczasu.pl/viewtopic.php?t=6630

http://www.tp.com.pl/turystyka/pelne-tajemnic-zachodnie-rubieze-mazowsza. html

http://www.woldenberg-neumark.eu/St/Woldenberger_Kirche.html\#loecher

http://zp.pl/kamien-pomorski-tajemnica-katedralnych-murow, artykul_1_534_0_30 